\title{
Ruthenium Nanoparticles in Ionic Liquids - A Saga
}

\author{
Paul S. Campbell ${ }^{* a}$, Martin H.G. Precht1 ${ }^{\text {b }}$, Catherine C. Santini*c ${ }^{* \mathrm{c}}$ and Paul-Henri Haumesser ${ }^{\mathrm{d}}$
}

\author{
${ }^{a}$ Anorganische Chemie III - Materialchemie, Fakultät für Chemie und Biochemie, Ruhr-Universität Bochum, Universitätstraße 150, \\ 44801 Bochum, Germany \\ ${ }^{b}$ Institut für Anorganische Chemie, Universität zu Köln, Greinstr. 6, 50939 Köln, Germany \\ ${ }^{c}$ Université de Lyon, Institut de Chimie de Lyon, C2P2, UMR 5265 CNRS - ESCPE Lyon, 43 bd du 11 Novembre 1918,69626 \\ Villeurbanne Cedex, France \\ ${ }^{d}$ CEA, LETI, MINATEC Campus, 17 rue des Martyrs, 38054 Grenoble Cedex 9, France
}

\begin{abstract}
Ionic liquids (ILs) are excellent media for the generation and stabilisation of metallic nanoparticles (NPs). Their ionic character coupled with 3-D structural pre-organisation in the liquid state, serves to direct the growth of transition metal NPs generated in situ, and to subsequently protect and stabilise them. Until now, many different NPs have been successfully synthesised within these media, however much attention has been paid to Ru-NPs. These have been prepared with small sizes and narrow size distributions by reduction of organometallic compounds with molecular hydrogen as well as decomposition of transition-metal complexes in the zero-valent state. These stable Ru-NPs immobilised in the ILs have proven to be efficient green catalysts for several reactions in multiphase conditions, including important energy-related processes such as biomass refinement. Furthermore, they present potential novel materials for use in the production of smarter electronic devices. In this review, the synthesis, stabilisation and size-control of Ru-NPs via various methods in different ILs is discussed, followed by their varied application in catalysis and potential in new fields.
\end{abstract}

Keywords: Ionic liquids, Ruthenium, Nanoparticles, Catalysis.

\section{INTRODUCTION}

Interest in metal nanoparticles (NPs) over the last decade has increased dramatically, as reflected by the ever-growing number of publications. Progress in their comprehension is central due to their great potential in the development of new and innovative materials. Catalysis is the traditional application of NPs, but they also find application in diverse fields such as photochemistry, electronics, optics or magnetism. In catalysis, improvement is constantly being made in the efficiency and selectivity of reactions and recovery and recyclability of the catalytic materials [1-7].

Nanoparticles are generally defined as particles exhibiting at least one dimension below $100 \mathrm{~nm}$, although of particular interest are those exhibiting dimensions less than $10 \mathrm{~nm}$. This leads not only to a high surface-to-volume ratio but also to unique physicochemical properties between the bulk and molecular states, which vary greatly with small changes in size. For instance, the catalytic properties of NPs are largely determined by the energy of the surface atoms, in turn controlled by the number of neighbouring atoms, dictated by their size, as well as the presence and nature of ligands or supports $[1,8,9]$.

To prepare NP catalysts via bottom-up chemical methods, a metal precursor and reducing agent or technique are required. For

"Address correspondence to these authors at the Anorganische Chemie I - Festkörperchemie und Materialen. Ruhr-Universität Bochum, Universtitätstraße 150, 44801 Bochum, Germany; Tel: +492343222043; Fax: +492343214951; E-mail: paul.campbell@rub.de, Institut für Anorganische Chemie, Universität zu Köln, Greinstr. 6, 50939 Köln, Germany; Tel: +492214701981; Fax: +492214701788; E-mail: martin.prechtl@uni-koeln.de and Université de Lyon, Institut de Chimie de Lyon, C2P2, UMR 5265 CNRS - ESCPE Lyon, 43 bd du 11 Novembre 1918, 69626 Villeurbanne Cedex, France; Tel: +33472431810; E-mail: catherine.santini@univ-lyon1.fr instance, the metal precursor can be a salt or organometallic complex, which can be reduced by applying $\mathrm{H}_{2}$ pressure, heating or addition of a reducing agent such as $\mathrm{NaBH}_{4}$ to result in bare zerovalent metal atoms. These atoms will subsequently meet and nucleate to form NPs, which must be somehow stabilised to prevent coalescence towards the thermodynamically stable bulk. Besides the polymers and oxide- supports that used to be employed as standard, innovative stabilisers, media, and supports have appeared, such as dendrimers, carbon nanotubes, membranes, specific ligands surfactants, and ionic liquids [10-12].

Soluble noble metal nanoparticles are now considered as an unavoidable family of catalysts, often described as "semi-heterogeneous catalysts", lying at the frontier between homogeneous and heterogeneous chemistry. To prevent aggregation, NPs must be stabilised by the use of water-soluble polymers, quaternary ammonium salts, surfactants or polyoxoanions, which provide electronic and/or steric protection $[3,4,10]$. In this context, ionic liquids (ILs), defined as low temperature molten salts, have emerged as one of the most important and most investigated classes of stabilising agent in the synthesis of metal NPs $[13,14]$.

ILs are salts that exhibit low melting points (below $100{ }^{\circ} \mathrm{C}$ ), many of which are liquid at room temperature. This is because they consist of large asymmetric organic cations weakly coordinated to an anion, which can be either organic or inorganic. The main cation and anion families to be discussed are given in Scheme $\mathbf{1}$ with their names and abbreviations. Thanks to their interesting physicochemical properties (negligible vapour pressure, low flammability, large liquidus range, wide electrochemical window etc.), ILs have found themselves at the forefront of modern chemical research, often dubbed as "green solvents" or "designer solvents". The latter is due to their facile adaptability, as with countless anion-cation 

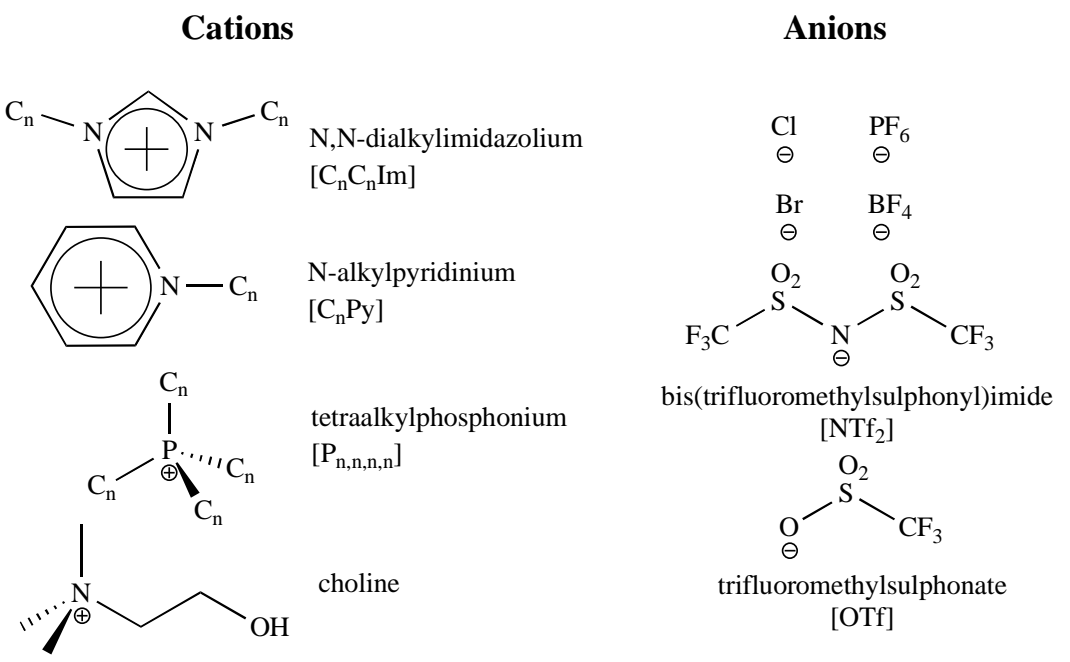

Scheme 1. Structures, names and abbreviations of ionic liquid cations and anions discussed herein.
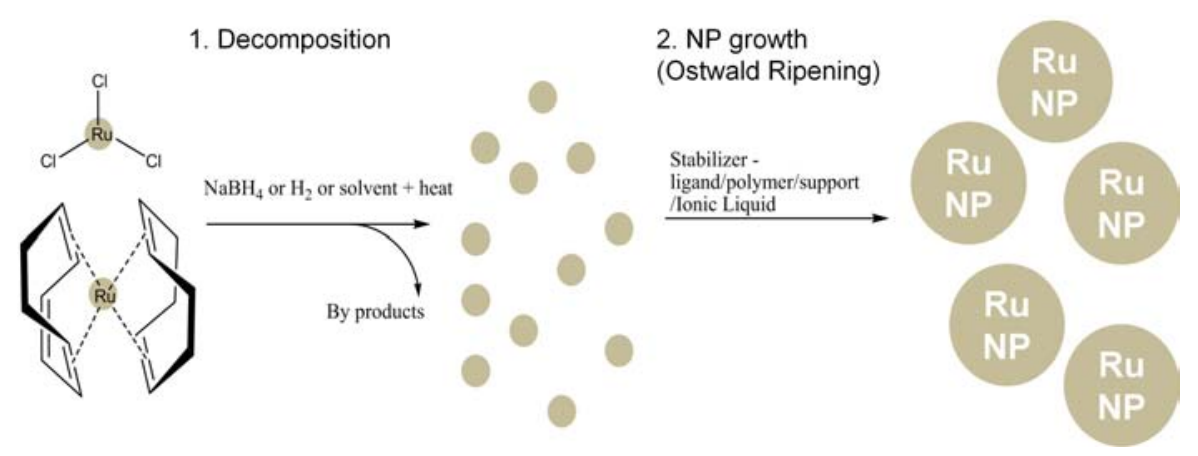

Scheme 2. The step-wise generation of ruthenium nanoparticle colloidal solutions.

combinations possible, small and simple modifications may be applied to alter the properties of an IL and tailor it to a specific task [15-18]. Their aptness as media for nanochemistry has been ascribed both to their ionic nature and to their 3-D organisation on the nanoscale. Indeed, much attention has particularly been paid to ILs based on $\mathrm{N}$-alkylimidazolium, found by molecular dynamics simulations and coarse-grain modelling to exhibit nano-structuration in the liquid state $[19,20]$. This may provide an "entropic driver" for the formation of nanostructures [21], while the formation of ionic double-layers provides a possible explanation for their subsequent stabilization [3].

NPs of many catalytically active transition metals have been reported in ILs [13, 14]. However, ruthenium NPs and ILs seem to have formed a particularly fruitful partnership, with unmatched small sizes (down to $0.9 \mathrm{~nm}$ reported), narrow size distributions (down to $\pm 0.2 \mathrm{~nm}$ ) and precise size control. As one of the catalytically active noble metals, ruthenium has been widely studied in both homogeneous catalysis, the most well known example being olefin metathesis [22, 23], and in heterogeneous, for example the partial hydrogenation of benzene to cyclohexene (Asahi process) [24], phenol hydrogenation [25], or in the synthesis of ammonia from N2 (Haber-Bosch process) [26, 27]. More recently, interest has also been devoted towards Ru-NPs, even though it is claimed by Galetti et al. that their preparation is more difficult and therefore less-investigated than other noble metals such as Pt or Pd [25]. Herein, our aim is to provide a review on the synthesis of ruthenium nanoparticles in ionic liquids and the potential of such systems in catalysis, from traditional hydrogenations, to more topical energy- related applications such as Fischer-Tropsch-Synthesis and biomass refinement.

\section{SYNTHESIS AND CHARACTERISATION OF RU-NPS IN IONIC LIQUIDS}

The study of Ru-NPs and their use in catalysis is not a new concept and dates back to the 1980s [28-31]. Grafting of catalytically active metal complexes onto oxide supports, a technique commonly referred to as "surface organometallic chemistry", was becoming a popular area of interest due to the prospect of combining the advantages of heterogeneous and homogeneous catalysis (i.e. obtaining recoverable, reusable catalysts with high activity and selectivity), as well as obtaining new and novel catalysts [32]. This method involves firstly impregnation of the support with a solution (aqueous or organic) of metal precursor, followed by elimination of the solvent and finally thermal treatment, generally under $\mathrm{H}_{2}$ or vacuum. However, for late transition metals such as ruthenium, after thermal treatment, these surface complexes, e.g. $\mathrm{Ru}_{3}(\mathrm{CO})_{12}$, tend to decompose and agglomerate, forming small oxide-supported Ru-NPs (1-2 nm on $\mathrm{SiO}_{2}$, measured by TEM) [28-31]. Nonetheless, these supported Ru-NPs were found to display interesting catalytic behaviour, for example in the hydrogenolysis and homologation of olefins $[33,34]$, and thus this approach has since been extended to many other supports such as mesoporous silica [35], alumina [36] and mesoporous polymers [37].

More recently, colloidal solutions of Ru-NPs have also received a considerable amount of attention. The synthesis of such colloids generally occurs via the same step-wise procedure (Scheme 2): 


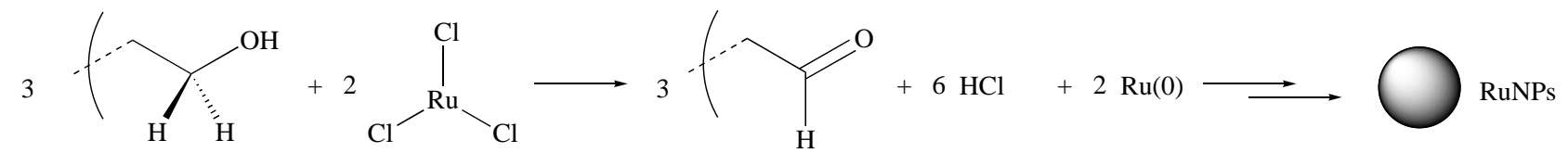

Scheme 3. Ruthenium nanoparticles produced via the polyol synthesis.

Firstly, a precursor is chosen, either a salt or organometallic complex of ruthenium, and dispersed in a suitable solvent, in the presence of a stabilising agent. In the second step, the precursor is reduced and/or decomposed under the given reaction conditions to give atomic zero-valent ruthenium. As coordinatively unsaturated species, these bare ruthenium atoms will agglomerate to form particles, a process known as Ostwald ripening. A stabilising agent is therefore necessary to limit the growth of these particles to the nanoscale.

Several variations of this procedure exist. For example, the socalled polyol synthesis involves firstly suspending the metal precursor in a polyol such as ethylene glycol, before bringing the resulting mixture to reflux and awaiting the precipitation of the metallic moieties. The reduction occurs via the simultaneous oxidation of alcohols to aldehydes as shown in Scheme 3. The resulting metal NPs can be filtered and dried in air. The polyol method has been used in the presence of various stabilisers such as dodecane-thiol as a capping agent [38], or supports such as polyvinylpyrrolidone (PVP) [39-42] and $\gamma$-alumina [26].

Zero-valent organometallic precursors are generally easily decomposed under $\mathrm{H}_{2}$ atmosphere rapidly producing NPs. The organic by-products can be easily removed without further interaction with the surface of the resulting NPs. For this reason, Chaudret and co-workers have thoroughly developed the synthesis of Ru-NPs in organic solvents, usually tetrahydrofuran, from the decomposition of the organometallic precursor cyclooctadiene cyclooctatriene ruthenium, $\mathrm{Ru}(\mathrm{COD})(\mathrm{COT})$. In this work it has been thoroughly proven that the size, shape and nature of the Ru-NPs produced could be controlled by varying the support and/or capping agent [43-47].

From an environmentally-friendly point of view, aqueous catalytic processes are a highly interesting concept. Motivated by this, Roucoux and coworkers have undertaken much work on the aqueous synthesis of Ru-NPs from reduction of $\mathrm{RuCl}_{3}$ with $\mathrm{NaBH}_{4}$ in the presence of cyclodextrins, which stabilise the resulting NPs by formation of inclusion complexes. The cyclodextrins, which are water-soluble, may also modify the surface of the Ru-NPs for specific reactivity [48-50]. Water-soluble $\mathrm{Ru}-\mathrm{NPs}$ have also been achieved using similar experimental conditions but with less complicated ligands such as ethylenediamine [51, 52], sodium acetate [53], or even polymers such as poly(4-vinylpyridine) [54].

As previously mentioned, all of the above routes to obtain $\mathrm{Ru}-$ NPs require the presence of additional stabilising agents in the form of either capping ligands, polymers or supports. In contrast, when using ionic liquids as the reaction medium, the synthesis of metallic NPs can take place with size-control in the absence of stabilising additives. The number of publications in this field is increasing exponentially, and these have recently been comprehensively reviewed [13]. Due to their specific solvation properties and 3-D structural organisation in the liquid state, ionic liquids are "supramolecular fluids" that can be used as "entropic drivers" for the spontaneous, well-defined and extended ordering of nanoscale structures.
Ru-NPs were first generated in ionic liquids during an investigation of the catalytic hydrogenation behaviour of $\mathrm{RuO}_{2}$ in these media $[55,56]$. Heavy metals such as mercury as well as molecules such as $\mathrm{CS}_{2}$ bind strongly and irreversibly to noble metals, therefore blocking active catalytic sites. $\mathrm{Hg}$ and $\mathrm{CS}_{2}$ poisoning tests can therefore be used to confirm or eliminate the participation of heterogeneous catalysts in a catalytic system. Addition of $\mathrm{Hg}$ or $\mathrm{CS}_{2}$ to the $\mathrm{RuO}_{2} / \mathrm{IL}$ system saw an immediate cease in catalytic activity, thus confirming that the catalytically active species was in fact colloidal $\mathrm{Ru}(0) \mathrm{NP}$ species formed in situ. The presence of Ru-NPs was confirmed by means of both transition electron microscopy, (TEM) and powder X-ray diffraction (XRD). XRD reflections were seen corresponding to hcp $\mathrm{Ru}(0)$ and a small amount of $\mathrm{RuO}_{2}$, although this was attributed to a small amount of surface reoxidation on separation from the ionic liquid, necessary for the measurement. Indeed, the ionic liquid seems to provide a protection for the particles against oxidation. Thanks to the negligible vapour pressure of ionic liquids, analytical techniques requiring high vacuum may be performed in situ. Therefore TEM was performed in situ immediately after catalysis, and removal of the volatiles. Small roughly spherical particles were observed with average diameters $2.5 \pm 0.4 \mathrm{~nm}$ in $\left[\mathrm{C}_{4} \mathrm{C}_{1} \mathrm{Im}\right]\left[\mathrm{PF}_{6}\right]$ and $\left[\mathrm{C}_{4} \mathrm{C}_{1} \mathrm{Im}\right][\mathrm{OTf}]$ and $2.0 \pm 0.2 \mathrm{~nm}$ in $\left[\mathrm{C}_{4} \mathrm{C}_{1} \mathrm{Im}\right]\left[\mathrm{BF}_{4}\right]$. This was a first indication that small $\mathrm{Ru}-\mathrm{NPs}$ with a very narrow size distribution could be generated under mild conditions $\left(75^{\circ} \mathrm{C}, 4\right.$ bars $\left.\mathrm{H}_{2}\right)$ in ionic liquids, with the ionic liquids stabilising them against both coalescence and oxidation.

Inspired by Chaudret's work in organic solvents, Dupont and co-workers embarked upon the generation of Ru-NPs in ILs by the decomposition of the organometallic precursor $\mathrm{Ru}(\mathrm{COD})(\mathrm{COT})$, for eventual use in biphasic catalysis [57]. Here a suspension of the precursor in various ILs $\left(\left[\mathrm{C}_{4} \mathrm{C}_{1} \mathrm{Im}\right]\left[\mathrm{BF}_{4}\right], \quad\left[\mathrm{C}_{4} \mathrm{C}_{1} \mathrm{Im}\right][\mathrm{OTf}]\right.$ and $\left[\mathrm{C}_{4} \mathrm{C}_{1} \mathrm{Im}\right]\left[\mathrm{PF}_{6}\right]$ ) was exposed to molecular $\mathrm{H}_{2}$ (4 bars) at $75^{\circ} \mathrm{C}$ for $18 \mathrm{~h}$, resulting in each case in the formation of a black suspension. $\mathrm{Ru}$-NPs could be isolated as a black powder by centrifugation for characterisation. XRD performed indicated the presence of pure phase hexagonal close packed ruthenium. The broad peaks observed could be explained by the small crystallite size. Indeed, reducing crystallite size to the nanoscale causes diffraction peak broadening as described by the Scherrer equation (Equation (1)), where $\tau$ is the nanoparticle size, $\beta$ is the line broadening and $\mathrm{K}$ is the shape factor. This equation could be applied to estimate a NP size of roughly $2.5 \mathrm{~nm}$, in good agreement with the value obtained from TEM results $(2.6 \pm 0.4 \mathrm{~nm})$.

$$
\text { (1) } \tau=\frac{K \lambda}{\beta \cos \theta}
$$

X-ray photo-electron spectroscopy (XPS) was also carried out, to give information on the elements present and oxidation states thereof. It was found that oxidised ruthenium and oxygen peaks were present, however disappeared after $\mathrm{Ar}^{+}$-sputtering, indicating only surface oxidation, probably due to exposure to air after separation from the ionic liquids. 

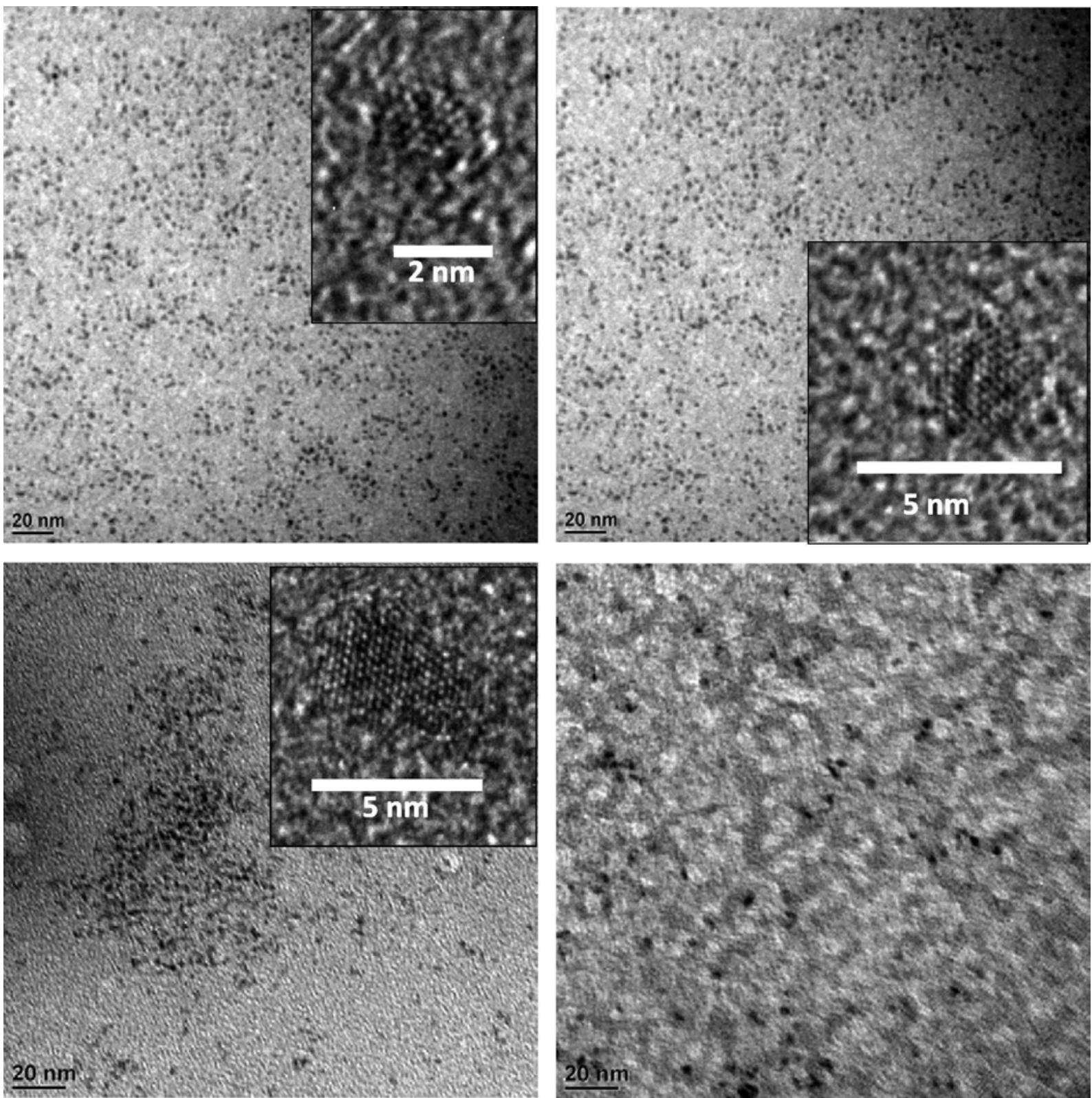

Fig. (1). Transition electron micrograph of Ru-NPs and high-resolution electron micrograph examples showing crystallinity for Ru-NPs produced in $\left[\mathrm{C}_{4} \mathrm{C}_{1} \mathrm{Im}\right]\left[\mathrm{NTf}_{2}\right]$ at $0{ }^{\circ} \mathrm{C}$ (top left), $25^{\circ} \mathrm{C}$ (top right), $50^{\circ} \mathrm{C}$ (bottom left) and $75^{\circ} \mathrm{C}$ (bottom right). [60] (Copyright Elsevier 2010).

Following on from this, Santini and co-workers undertook a systematic study of the synthesis of Ru-NPs from Ru(COD)(COT) under various conditions, particularly in imidazolium ILs based on the bis(trifluoromethylsulfonyl)imide $\left(\mathrm{NTf}_{2}^{-}\right)$ion, rendering highly interesting results [58]. Firstly, it was uncovered that, unlike in traditional solvents [59], decreasing the temperature of decomposition (hence decreasing rate of nucleation) leads to smaller NPs. Furthermore, it was seen that stirring during the decomposition has a negative impact on the size distribution. Ru-NPs were produced from a $\mathrm{Ru}(\mathrm{COD})(\mathrm{COT})$ suspension in $\left[\mathrm{C}_{4} \mathrm{C}_{1} \mathrm{Im}\right]\left[\mathrm{NTf}_{2}\right]$ under 4 bars $\mathrm{H}_{2}$, at $25{ }^{\circ} \mathrm{C}$ while stirring and at $0{ }^{\circ} \mathrm{C}$, with and without stirring. When stirred at $25^{\circ} \mathrm{C}$, NPs of $2.4 \pm 0.3 \mathrm{~nm}$ (determined by TEM) were generated, whereas at $0^{\circ} \mathrm{C}$, the size was reduced to $0.9 \pm 0.4 \mathrm{~nm}$. Furthermore at $0{ }^{\circ} \mathrm{C}$ without stirring during the decomposition, NPs of a similar size but narrower size distribution $(1.1 \pm 0.2 \mathrm{~nm})$ were obtained. These findings were later utilised to produce Ru-NPs of distinct and controlled sizes in the same ionic liquid for catalytic tests, by simply varying the decomposition temperature of $\mathrm{Ru}(\mathrm{COD})(\mathrm{COT})$. Under 4 bars of molecular $\mathrm{H}_{2}$, without stirring, Ru-NPs were produced of sizes (determined from TEM images, Fig. 1) $2.3 \pm 0.3 \mathrm{~nm}, 2.9 \pm 0.4 \mathrm{~nm}$ and $3.1 \pm 0.7 \mathrm{~nm}$ at $25^{\circ} \mathrm{C}, 50{ }^{\circ} \mathrm{C}$ and $75{ }^{\circ} \mathrm{C}$, respectively, further corroborating the idea of size control with temperature [60]. Shown in insets in Fig. 1, high resolution electron microscopy, HREM, revealed the hcp crystalline nature of these Ru-NPs formed through elucidation of the crystal planes. Furthermore, these NPs were found by means of XPS to be of pure zero-valent ruthenium: The low $3 \mathrm{p}_{3 / 2}$ binding energy observed in each case, $460.3 \mathrm{eV}$, and doublet separation of $22.2 \mathrm{eV}$ correspond closely to metallic zero-valent ruthenium. It should be noted that XPS performed in situ in the ionic liquid, resulted in no $\mathrm{Ru}$ binding energies being observed, as only electrons from the top $10 \mathrm{~nm}$ of the material may be detected using this technique [60]. 


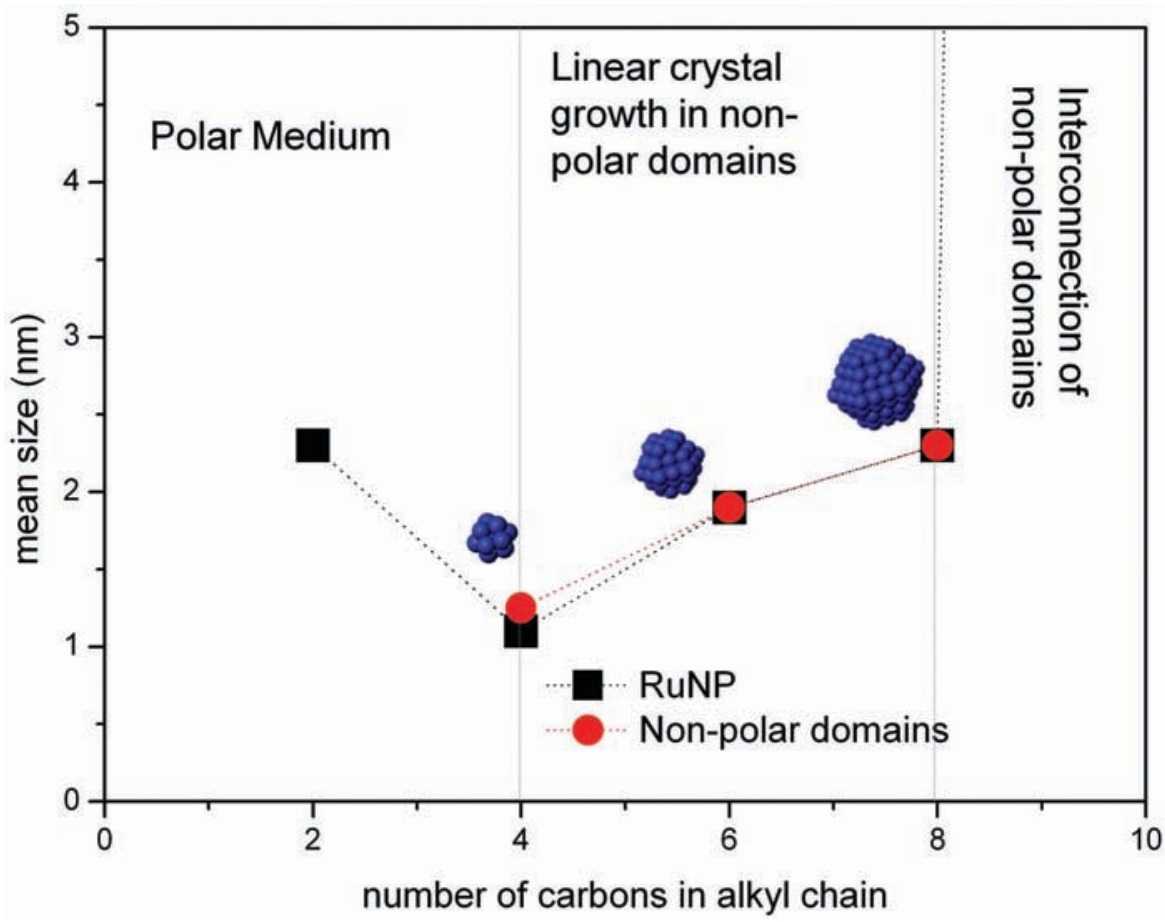

Fig. (2). Correlation between the length of the imidazolium alkyl chain and the Ru-NP size. Adapted from [62]

In addition to size-control by varying conditions, modulating the nature of the ionic liquid plays an important role. For example, Santini and coworkers also found that when synthesising Ru-NPs under the same conditions from $\mathrm{Ru}(\mathrm{COD})(\mathrm{COT})\left(0{ }^{\circ} \mathrm{C}, 4\right.$ bars $\mathrm{H}_{2}$, no stirring), in imidazolium ionic liquids of varying side alkyl chain length, the size of Ru-NP produced could be tuned [21]. This result could be explained by considering the molecular structure of the ionic liquid. Indeed, ILs are not homogeneous media but present a certain degree of self organisation on the molecular level. It has been found by molecular dynamics simulations [19] and coarsegrain modeling [20] that alkyl imidazolium ionic liquids consist of rigid ionic channels, built from the hydrogen-bonded network of anions and cation head-groups, and segregated lipophilic domains, the size of which depending ultimately on the length of the alkyl chains. These findings have also been demonstrated experimentally by X-ray diffraction studies [61]. Of course, an organometallic precursor would dissolve preferentially within these lipophilic domains. After decomposition, the size of the resulting Ru-NPs is dictated by the number of available nuclides in the non-polar domain, which is in turn related to its size and hence the length of the alkyl chain. This explains why a trend was observed correlating RuNP size with alkyl chain length. Indeed, as can be seen in Figure 2 for $\mathrm{n}=4,6$, and 8 , Ru-NP size matches almost perfectly the previously measured non-polar domain sizes, while for $\mathrm{n}=10$, an interconnection of non-polar domains leads to Ru-NP superstructures. When short alkyl chains are employed $(n=2)$ a purely polar domain is obtained and the size control is lost [21].

The IL structure can also be used to explain how reaction conditions affect the size of resulting Ru-NPs. At low temperature, diffusion of the precursor and nuclides between these domains is limited, hence the growth of NPs is restricted. Stirring disrupts the organisation through mechanical forces and increases the diffusion of the precursor and nuclides in solution. The resulting size distri- butions are therefore broader and the resulting NPs are agglomerated [58].

In addition, it has been shown that the ionic liquid structure may play a role in the subsequent stabilisation of the Ru-NPs. Indeed, Ru-NPs produced in imidazolium ILs under these conditions render suspensions stable for months under inert atmosphere without any agglomeration, coalescence or sintering of particles observed. Following the synthesis of Ru-NPs under $\mathrm{D}_{2}$ in ILs bearing unsaturated functionalities (butenyl, benzyl) on the alkyl side chain, a strong proximity between the Ru-NP surface and this group was brought to light; ${ }^{2} \mathrm{H}$ NMR revealed preferential incorporation of $\mathrm{D}$ into these groups via H-D exchange catalysed by the metal surface, rather than the expected H-D exchange at the more acidic positions on the imidazolium ring. A significant amount of hydrogenation was also noted, elucidated through the evolution of high field shifts corresponding to deuterium-bearing aliphatic butenyl or methylenecyclohexyl groups [63].

While the confinement in non-polar domains may provide an explanation for the non-agglomeration of the NPs whilst in the suspension, it cannot account for the lack of coalescence noted when the IL structure is disrupted by the addition of a co-solvent. It was found, through H-D exchange and ethylene hydrogenation in the absence of additional $\mathrm{H}_{2}$, that $\mathrm{Ru}$-NPs prepared from the decomposition of $\mathrm{Ru}(\mathrm{COD})(\mathrm{COT})$ under $\mathrm{H}_{2}$ in imidazolium ILs are in fact covered by surface hydrides [63], a result which was previously similarly demonstrated for Ru-NPs in both organic solvents [64], and supported on silica $[65,66]$. The idea of NP stabilisation in ILs by a combination of surface hydrides and confinement in non-polar domains of the IL is similar to that previously reported in organic media (see Fig. 3), and in stark contrast to the often described "electrosteric stabilisation" model in ionic liquids, whereby the electropositive NP surface is surrounded by a double-layer of anions and cations forming a protective shell through electrostatic and DVLO type forces [67-72]. 

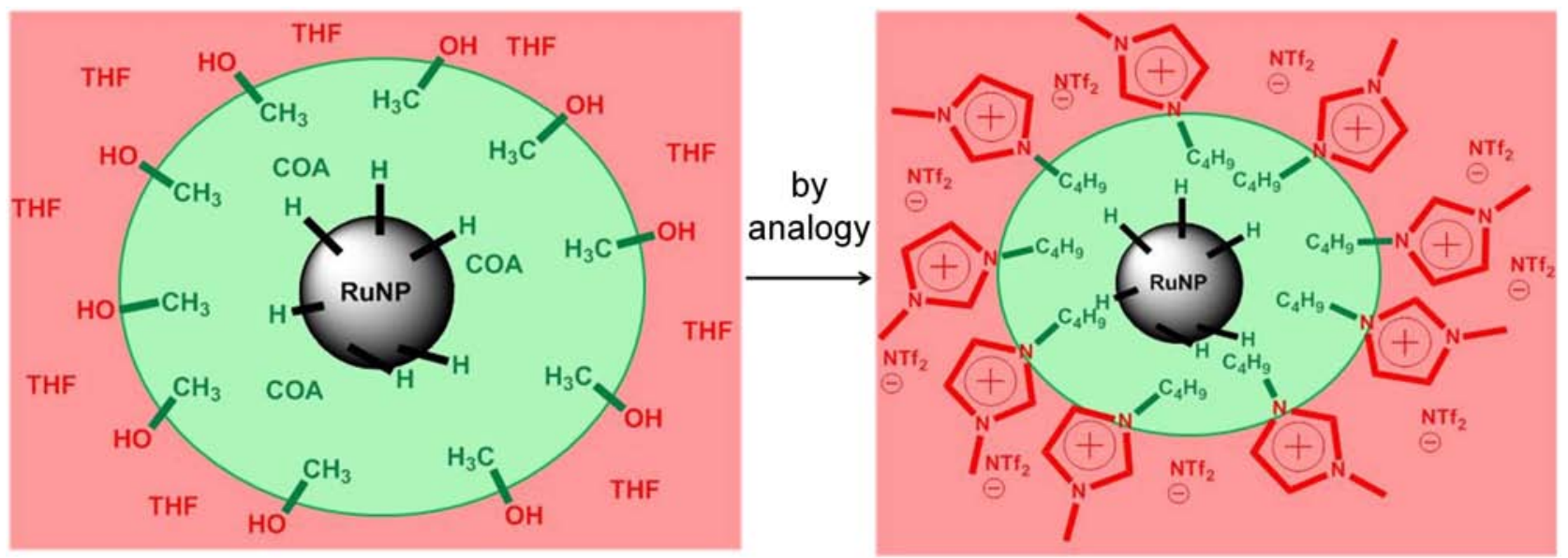

Fig. (3). A stabilisation model for Ru-NPs in MeOH/THF solution and analogous proposal in the IL [C4C1Im][NTf2]. Inside circle represents non-polar domains and outside represents polar or ionic media. $\mathrm{COA}=$ cyclooctane. Adapted from [73].

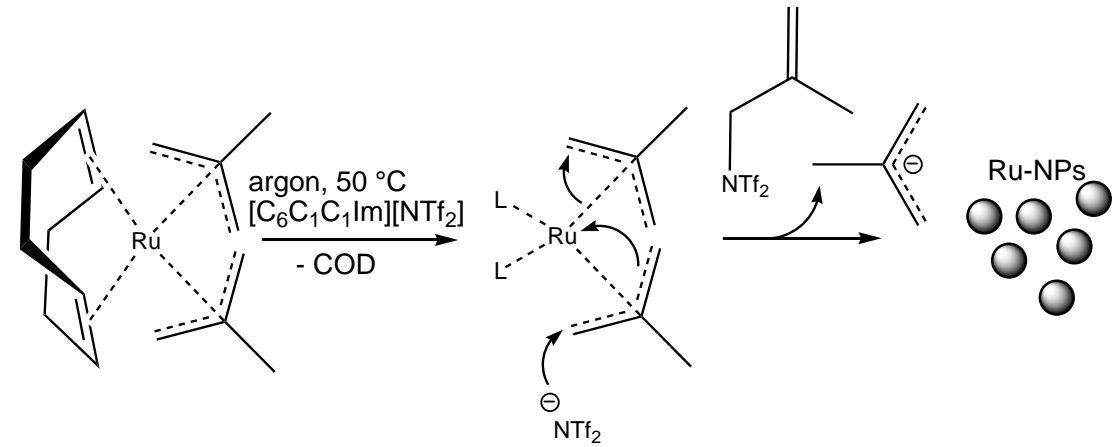

Scheme 4. Generation of Ru-NPs promoted by the $\mathrm{NTf}_{2}$ anion, without the addition of $\mathrm{H}_{2}$.

Another organometallic precursor, namely bis(2methylallyl $)\left(\eta^{4}-1,5\right.$-cyclooctadiene)ruthenium $\quad\left(\mathrm{Ru}(\mathrm{COD})(\mathrm{MA})_{2}\right)$ has been investigated as an alternative due to its commercial availability and lower cost [74, 75]. Unlike in $\mathrm{Ru}(\mathrm{COD})(\mathrm{COT})$, in $\mathrm{Ru}(\mathrm{COD})(\mathrm{MA})_{2}$ ruthenium exists in the $2+$ oxidation state, hence must be reduced in order to obtain zero-valent metallic Ru-NPs. Nonetheless, it was found that Ru-NPs could still be obtained under mild conditions $\left(25-90^{\circ} \mathrm{C}, 4\right.$ bars $\left.\mathrm{H}_{2}\right)$ after dispersion of this precursor in various imidazolium ILs [74]. This study confirmed the previously discussed temperature dependence of the resulting $\mathrm{Ru}-\mathrm{NP}$ size as well as highlighting the importance of the IL anion. Indeed, it was shown that when using $\mathrm{BF}_{4}{ }^{-}$as the counter ion, the Ru-NPs could be removed from the suspension via addition of a solvent and centrifugation, whereas when $\mathrm{NTf}_{2}^{-}$was used the colloidal suspension could not be separated [74]. Similarly, Leitner's group used $\mathrm{Ru}(\mathrm{COD})(\mathrm{MA})_{2}$ to produce $\mathrm{Ru}-\mathrm{NPs}$ in a range of imidazolium ILs. Although harsher conditions were employed $\left(60{ }^{\circ} \mathrm{C}, 60\right.$ bars $\left.\mathrm{H}_{2}\right)$, similar size particles were obtained, indicating that $\mathrm{H}_{2}$ pressure plays only a minor role [76].

In contrast to $\mathrm{Ru}(\mathrm{COD})(\mathrm{COT})$, reduction of $\mathrm{Ru}(\mathrm{COD})(\mathrm{MA})_{2}$ in the ILs was also seen to lead to the evolution of small amounts of odorous by-products, found by mass spectrometry to be small nitrogen containing organics from the fragmentation of the imidazolium ring. This reactivity is promoted by the presence of $\mathrm{Ru}(\mathrm{COD})(\mathrm{MA})_{2}$ but not the resulting Ru-NPs. More interestingly, in certain ILs, particularly $\left[\mathrm{C}_{6} \mathrm{C}_{1} \mathrm{C}_{1} \mathrm{Im}\right]\left[\mathrm{NTf}_{2}\right]$, this precursor is slowly reduced to form zero-valent $\mathrm{Ru}-\mathrm{NPs}$, confirmed by TEM and HRTEM, without the introduction of $\mathrm{H}_{2}$ gas. The proposed mechanism of this involves a nucleophilic attack by the $\mathrm{NTf}_{2}$ ion on the allyl ligand, followed by reductive elimination leading to $\mathrm{Ru}(0)$ atoms, subsequently forming NPs, Scheme 4. This comprises the first report of ILs also being responsible for promoting the generation of Ru-NPs as well as their stabilization [75].

An interesting recent study conducted by Luska et al. found a correlation between Ru-NP stability and ionicity of the IL used. Here, when $\mathrm{Ru}(\mathrm{COD})(\mathrm{MA})_{2}$ was reduced in various phosphonium ILs, of varying alkyl chain lengths, as well as imidazolium ILs, the size distribution and tendency to agglomerate was discovered to increase with increasing calculated ionicity. In other words, greater association between cation and anion leads to more stable Ru-NPs, an affirmation which corroborates the role of IL structuration in $\mathrm{Ru}$ NP stability [77].

As another alternative precursor, Zhu and coworkers [78] found that the dinuclear ionic sandwich complex, $\left[\mathrm{CpRuCp} * \mathrm{RuCp}^{*}\right]\left[\mathrm{PF}_{6}\right]$ could be dispersed in ILs with the aid of ethylene glycol as a cosolvent, and reduced to give Ru-NPs under a $\mathrm{H}_{2}$ atmosphere at $180{ }^{\circ} \mathrm{C}$. Both $\left[\mathrm{C}_{4} \mathrm{C}_{1} \mathrm{Im}\right]\left[\mathrm{PF}_{6}\right]$ and $\left[\mathrm{P}_{6,6,6,14}\right][\mathrm{DBS}]\left(\mathrm{P}_{6,6,6,14}=\right.$ tri(hexyl)tetradecylphosphonium, DBS = dodecylbenzenesulphonate) could be used, the latter eliminating the possibility of HF production or N-heterocyclic carbene formation. The ethylene glycol could easily separated by decantation and drying leaving a clean Ru-NP/IL suspension stable for months [78, 79].

Other methods for the generation of Ru-NPs in ILs exist. Janiak's group have been particularly interested in the thermally assisted or photolytic decomposition of metal carbonyls including trinuclear ruthenium carbonyl $\left(\mathrm{Ru}_{3}(\mathrm{CO})_{12}\right)$ in the $\mathrm{IL}\left[\mathrm{C}_{4} \mathrm{C}_{1} \mathrm{Im}\right]\left[\mathrm{BF}_{4}\right]$ [80-83]. In thermally assisted syntheses, a mixture of the precursor in IL was heated to $250^{\circ} \mathrm{C}$ for several hours, leading to small monodisperse Ru-NPs, $1.6 \pm 0.4 \mathrm{~nm}$ analysed by TEM. In photo- 


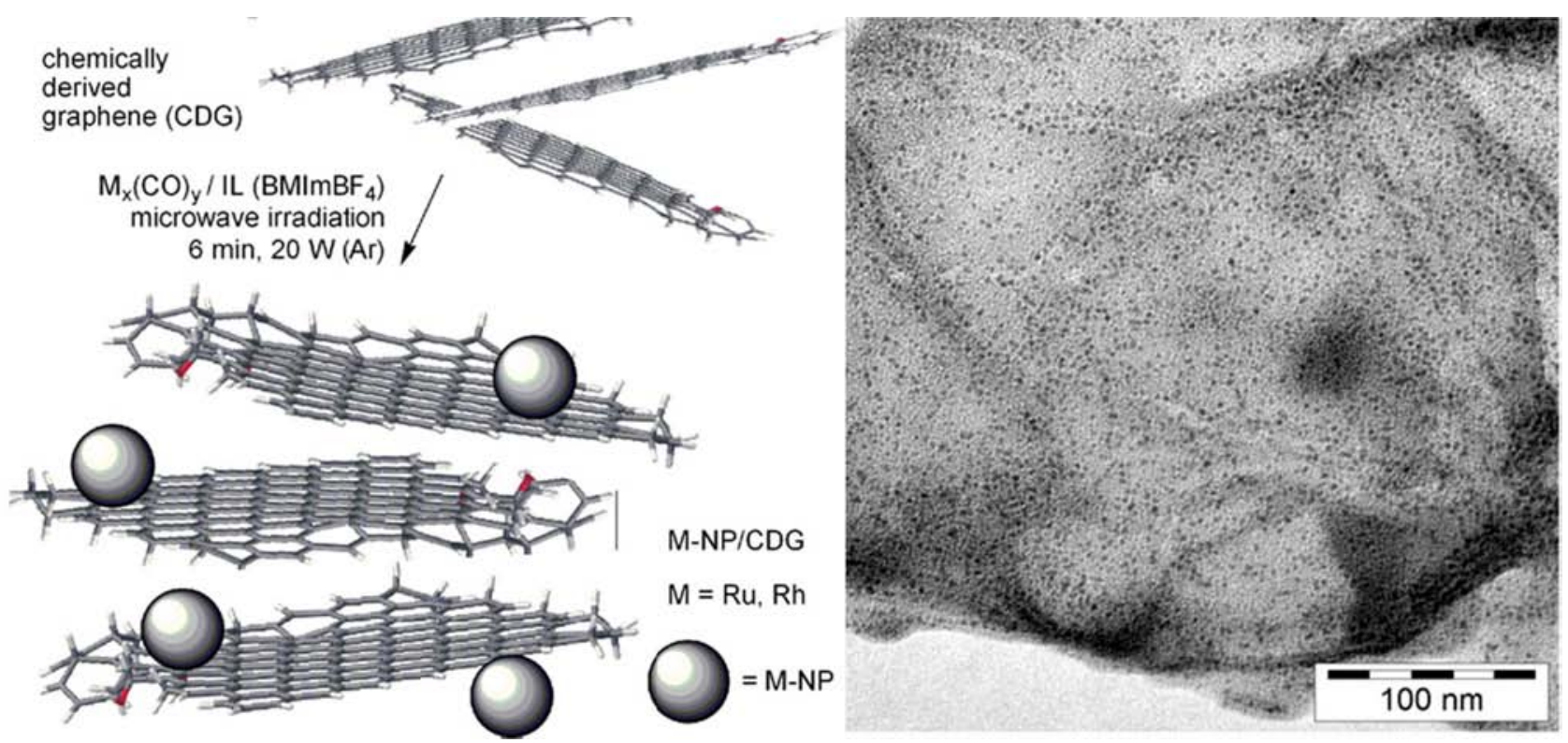

Fig. (4). The synthesis of single-sheet graphene supported Ru-NPs in the IL [C4C1Im] $\left.\mathrm{BF}_{4}\right]$, and TEM image of material obtained. Image adapted from [84] (Copyright Elsevier 2011).

lytic decomposition, the mixture was exposed to $1000 \mathrm{~W}$ broad UV radiation for 15 minutes. The particles obtained by this method were found to be of a larger size, $2.0 \pm 0.5 \mathrm{~nm}$, as explained by the more rapid and less controlled reaction. In this study, dynamic light scattering (DLS) was also used to estimate particle size. This method rendered sizes slightly larger than those estimated by TEM, explained by the fact that DLS is used to calculate the size of an object moving through a solution, which may include the particle and surrounding protective shell of molecules [80]. As well as conventional heating, microwave heating has been found to be a useful alternative. Ionic liquids containing large ions presenting high polarisability are particularly susceptible to MW radiation and reach high heating rates. Indeed, at a power of only $10 \mathrm{~W}$ in a laboratory microwave the suspension reached the $250{ }^{\circ} \mathrm{C}$ required in less than 1 minute, presenting a clear advantage over the conventional heating route, and leading to Ru-NPs of an almost identical size and size distribution [81].

Despite the intrinsic ability of ILs to stabilise Ru-NPs synthesised in situ, under catalytic conditions, i.e. elevated temperature and stirring, Ru-NPs tend to diffuse through solution to slowly agglomerate and coalesce. It may therefore be advantageous to introduce additional stabilising agents as an added barrier to agglomeration and catalyst deactivation. For example, Janiak's group has produced Ru-NPs supported on chemically derived graphene (CDG) by simply introducing this into $\left[\mathrm{C}_{4} \mathrm{C}_{1} \mathrm{Im}\right]\left[\mathrm{BF}_{4}\right]$ to obtain stable dispersion of single graphene sheets, before carrying out the $\mathrm{MW}$-assisted decomposition of $\mathrm{Ru}(\mathrm{CO})_{13}$ previously described, (Fig. 4). The resulting material could be separated from the IL by centrifugation and TEM measurements found small-size supported Ru-NPs with narrow size distribution [84]. Furthermore, Jiang et al. found the IL 1,1,3,3-tetramethylguanadinium (TMG) lactate could be used to immobilise NPs in mesoporous silica (SBA-15). Here, the precursor used was $\mathrm{RuCl}_{3}$, which was reduced under $\mathrm{H}_{2}$ at $150{ }^{\circ} \mathrm{C}$ in the presence of both the IL and SBA support to give $\mathrm{Ru}-$ NPs sized between 2 and $5 \mathrm{~nm}$ [85].

The addition of ligands is yet another possibility to better the stability of the resulting Ru-NPs. For this reason, hexadecylamine (HDA) and octylamine (OA) were used in combination with imida- zolium ILs, to produce Ru-NPs from $\mathrm{Ru}(\mathrm{COD})(\mathrm{COT})$ [86]. Alkylamines are labile ligands often used as capping agents in the synthesis of Ru-NPs in organic solvents. The presence of the ligand enhanced the size control of the Ru-NPs formed, both with respect to those synthesised in amine/THF mixtures and those synthesised in ILs without ligands under the same conditions. Regardless of the temperature or IL employed, sizes measured by TEM fell in the range 1.1-1.3 nm with very narrow size distributions. A combination of ${ }^{13} \mathrm{C}$ and DOSY (Diffusional Order SpectroscopY) NMR measurements of the colloidal solution with OA reported the absence of NMR signal for the $\alpha$-carbon plus a low diffusion coefficient for OA, proving the coordination of the amine to the surface of the Ru-NPs [86]. Furthermore, it was suggested by ${ }^{13} \mathrm{C}$ spectra that addition of different quantities of amine leads to different coordination modes at the surface. At low amine concentration the amine alkyl chain lies close to the surface of the Ru-NP while at higher amine concentration, the alkyl chain points away from the surface, as illustrated in (Fig. 5). Interestingly, when amine is added after the synthesis of Ru-NPs, it causes flocculation of the Ru-NPs, probably due to the strong OA-OA affinity [87].

Additional stabilisation may even come from the IL itself; ILs are intrinsically highly adaptable species, which can be tailored to a specific task. For example, an imidazolium IL bearing a nitrilefunctionalised alkyl chain $\left[\left(\mathrm{C}_{3} \mathrm{CN}\right) \mathrm{C}_{1} \operatorname{Im}\right]\left[\mathrm{NTf}_{2}\right]$ has already been employed in the synthesis of Ru-NPs from $\mathrm{Ru}(\mathrm{COD})(\mathrm{MA})_{2}$ under $\mathrm{H}_{2}$, rendering small and stable Ru-NPs of $2.2 \pm 0.5 \mathrm{~nm}$ [88]. Such additional stabilisers may affect not only the stability of the Ru-NPs but also their catalytic properties, as will be discussed in the following section.

\section{RUTHENIUM NANOPARTICLES AS RECYCLABLE CATALYSTS IN IONIC LIQUIDS}

Ruthenium nanoparticles (Ru-NPs) dispersed in ionic liquids (ILs) are suitable systems for running both typical homogeneous and heterogeneous catalysis. This includes; hydrogenation of C-C and carbon hetero-atom multiple bonds and arenes [55-57, 60, 74, $75,81,82,84,88-95]$. dehydrogenation in transfer-hydrogenation processes [95], nitro-group reduction [96], hydrodeoxygenation [97], 

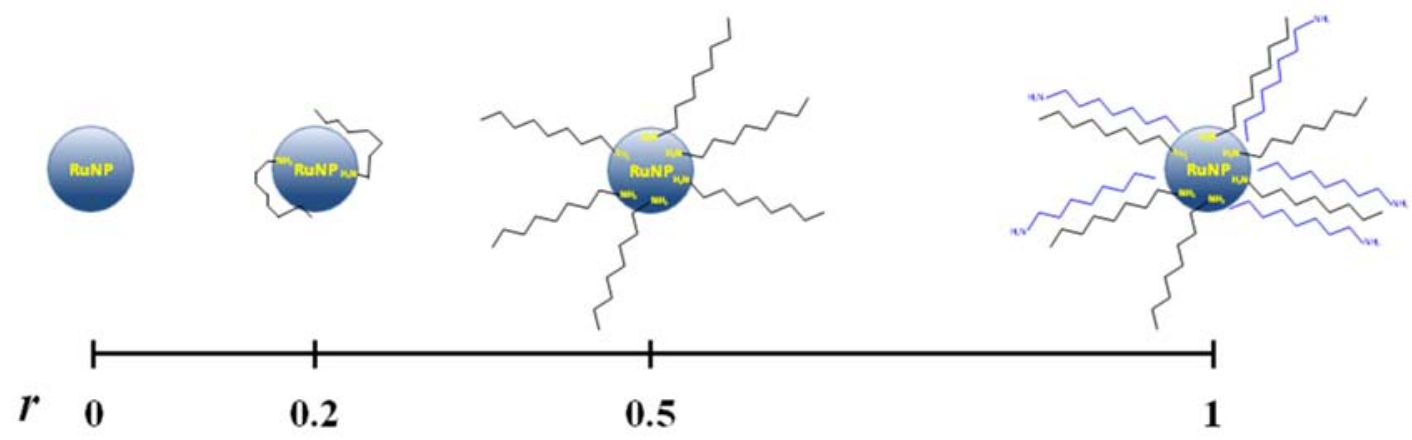

Fig. (5). Schematic illustration of the coordination of OA to Ru-NPs and the association OA-OA, where $r$ represents the molar ratio, OA:Ru.

Table 1. Glossary of Ru-NPs synthesised in ionic liquids

\begin{tabular}{|c|c|c|c|c|c|c|}
\hline Precursor & Conditions & Stirred & Ionic Liquid & Additive & Size obtained (nm) & Ref. \\
\hline $\mathrm{Ru}(\mathrm{COD})(\mathrm{COT})$ & $\begin{array}{l}0{ }^{\circ} \mathrm{C}, \mathrm{H}_{2}(4 \text { bar }) \\
0{ }^{\circ} \mathrm{C}, \mathrm{H}_{2}(4 \text { bar }) \\
\left.25^{\circ} \mathrm{C}, \mathrm{H}_{2} \text { (4 bar }\right)\end{array}$ & $\begin{array}{l}\text { Yes } \\
\text { No } \\
\text { Yes }\end{array}$ & $\begin{array}{l}{\left[\mathrm{C}_{4} \mathrm{C}_{1} \operatorname{Im}\right]\left[\mathrm{NTf}_{2}\right]} \\
{\left[\mathrm{C}_{4} \mathrm{C}_{1} \operatorname{Im}\right]\left[\mathrm{NTf}_{2}\right]} \\
{\left[\mathrm{C}_{4} \mathrm{C}_{1} \mathrm{Im}\right]\left[\mathrm{NTf}_{2}\right]}\end{array}$ & & $\begin{array}{l}0.9 \pm 0.4 \text { (agglomerated in } 2-3 \mathrm{~nm} \\
\text { clusters ) } \\
1.1 \pm 0.2 \\
2.4 \pm 0.3\end{array}$ & [58] \\
\hline $\mathrm{Ru}(\mathrm{COD})(\mathrm{COT})$ & $\begin{array}{l}25^{\circ} \mathrm{C}, \mathrm{H}_{2}(4 \text { bar }) \\
50^{\circ} \mathrm{C}, \mathrm{H}_{2}(4 \text { bar }) \\
\left.75^{\circ} \mathrm{C}, \mathrm{H}_{2} \text { (4 bar }\right)\end{array}$ & $\begin{array}{l}\text { No } \\
\text { No } \\
\text { No }\end{array}$ & $\begin{array}{l}{\left[\mathrm{C}_{4} \mathrm{C}_{1} \operatorname{Im}\right]\left[\mathrm{NTf}_{2}\right]} \\
{\left[\mathrm{C}_{4} \mathrm{C}_{1} \operatorname{Im}\right]\left[\mathrm{NTf}_{2}\right]} \\
{\left[\mathrm{C}_{4} \mathrm{C}_{1} \operatorname{Im}\right]\left[\mathrm{NTf}_{2}\right]}\end{array}$ & & $\begin{array}{l}2.3 \pm 0.3 \\
2.9 \pm 0.4 \\
3.1 \pm 0.7\end{array}$ & {$[60]$} \\
\hline $\mathrm{Ru}(\mathrm{COD})(\mathrm{COT})$ & $0{ }^{\circ} \mathrm{C}, \mathrm{H}_{2}$ (4 bar) & No & $\begin{array}{l}{\left[\mathrm{C}_{2} \mathrm{C}_{1} \mathrm{Im}\right]\left[\mathrm{NTf}_{2}\right]} \\
{\left[\mathrm{C}_{4} \mathrm{C}_{1} \mathrm{Im}\right]\left[\mathrm{NTf}_{2}\right]} \\
{\left[\mathrm{C}_{6} \mathrm{C}_{1} \mathrm{Im}\right]\left[\mathrm{NTf}_{2}\right]} \\
{\left[\mathrm{C}_{8} \mathrm{C}_{1} \mathrm{Im}\right]\left[\mathrm{NTf}_{2}\right]} \\
{\left[\mathrm{C}_{10} \mathrm{C}_{1} \mathrm{Im}\right]\left[\mathrm{NTf}_{2}\right]} \\
{\left[\mathrm{C}_{4} \mathrm{C}_{1} \mathrm{C}_{1} \mathrm{Im}\right]\left[\mathrm{NTf}_{2}\right]} \\
\mathrm{C}_{4} \mathrm{C}_{4} \mathrm{Im} \mathrm{NTf}{ }_{2}\end{array}$ & & $\begin{array}{l}2.3 \pm 0.6 \\
1.1 \pm 0.2 \\
1.9 \pm 0.6 \\
2.3 \pm 0.8 \\
100-150 \text { sponges } \\
1.8 \pm 0.5 \\
2.0 \pm 0.6\end{array}$ & {$[21]$} \\
\hline $\mathrm{Ru}(\mathrm{COD})(\mathrm{COT})$ & $30{ }^{\circ} \mathrm{C}, \mathrm{H}_{2}(4$ bar $)$ & $\begin{array}{l}\text { Yes } \\
\text { No } \\
\text { Yes } \\
\text { Yes } \\
\text { Yes } \\
\text { Yes }\end{array}$ & $\begin{array}{l}{\left[\mathrm{C}_{4} \mathrm{C}_{1} \operatorname{Im}\right]\left[\mathrm{NTf}_{2}\right]} \\
{\left[\mathrm{C}_{4} \mathrm{C}_{1} \operatorname{Im}\right]\left[\mathrm{NTf}_{2}\right]} \\
{\left[\mathrm{C}_{4} \mathrm{C}_{1} \operatorname{Im}\right]\left[\mathrm{NTf}_{2}\right]} \\
{\left[\mathrm{C}_{6} \mathrm{C}_{1} \operatorname{Im}\right]\left[\mathrm{NTf}_{2}\right]} \\
{\left[\mathrm{C}_{8} \mathrm{C}_{1} \operatorname{Im}\right]\left[\mathrm{NTf}_{2}\right]} \\
{\left[\mathrm{C}_{10} \mathrm{C}_{1} \mathrm{Im}\right]\left[\mathrm{NTf}_{2}\right]}\end{array}$ & $\begin{array}{l}\mathrm{HDA} \\
\mathrm{OA} \\
\mathrm{OA} \\
\mathrm{OA} \\
\mathrm{OA} \\
\mathrm{OA}\end{array}$ & $\begin{array}{l}1.3 \pm 0.4 \\
1.2 \pm 0.4 \\
1.1 \pm 0.3 \\
1.2 \pm 0.3 \\
1.2 \pm 0.3 \\
1.3 \pm 0.4\end{array}$ & {$[86]$} \\
\hline $\mathrm{Ru}(\mathrm{COD})(\mathrm{MA})_{2}$ & $50^{\circ} \mathrm{C}, \mathrm{H}_{2}(4$ bar $)$ & Yes & $\begin{array}{l}{\left[\mathrm{C}_{4} \mathrm{C}_{1} \mathrm{Im}\right]\left[\mathrm{NTf}_{2}\right]} \\
{\left[\mathrm{C}_{4} \mathrm{C}_{1} \mathrm{Im}\right]\left[\mathrm{BF}_{4}\right]} \\
{\left[\mathrm{C}_{10} \mathrm{C}_{1} \mathrm{Im}\right]\left[\mathrm{NTf}_{2}\right]} \\
{\left[\mathrm{C}_{10} \mathrm{C}_{1} \mathrm{Im}\right]\left[\mathrm{BF}_{4}\right]} \\
{\left[\left(\mathrm{C}_{3} \mathrm{CN}\right) \mathrm{C}_{1} \mathrm{Im}\right]} \\
{\left[\mathrm{NTf}_{2}\right]}\end{array}$ & & $\begin{array}{l}2.1 \pm 0.5 \\
2.9 \pm 0.5 \\
2.7 \pm 0.5 \\
2.1 \pm 0.5 \\
2.2 \pm 0.5\end{array}$ & {$[74,88]$} \\
\hline $\mathrm{Ru}(\mathrm{COD})(\mathrm{MA})_{2}$ & $60^{\circ} \mathrm{C}, \mathrm{H}_{2}(60$ bar $)$ & Yes & $\begin{array}{l}{\left[\mathrm{C}_{2} \mathrm{C}_{1} \mathrm{C}_{1} \mathrm{Im}\right]\left[\mathrm{NTf}_{2}\right]} \\
{\left[\mathrm{C}_{12} \mathrm{C}_{1} \mathrm{Im}\right]\left[\mathrm{NTf}_{2}\right]} \\
{\left[\mathrm{C}_{2} \mathrm{C}_{1} \mathrm{Im}\right]\left[\mathrm{NTf}_{2}\right]} \\
{\left[\mathrm{C}_{2} \mathrm{C}_{1} \mathrm{Im}\right][\mathrm{Br}]} \\
\\
{\left[\mathrm{C}_{2} \mathrm{C}_{1} \mathrm{Im}\right][\mathrm{AcO}]} \\
{\left[\mathrm{C}_{4} \mathrm{C}_{1} \mathrm{Im}\right]\left[\mathrm{BF}_{4}\right]}\end{array}$ & & $\begin{array}{l}\text { agglomerates } \\
2.7 \pm 0.2 \\
2.4 \pm 0.2 \\
2.5 \pm 0.5+\text { agglomerates } \\
2.3 \pm 0.2 \\
2.0 \pm 0.2\end{array}$ & [76] \\
\hline
\end{tabular}


Table 1. contd....

\begin{tabular}{|c|c|c|c|c|c|c|}
\hline Precursor & Conditions & Stirred & Ionic Liquid & Additive & Size obtained (nm) & Ref. \\
\hline $\mathrm{Ru}(\mathrm{COD})(\mathrm{MA})_{2}$ & $50^{\circ} \mathrm{C}, \mathrm{H}_{2}(4$ bar $)$ & Yes & $\begin{array}{l}{\left[\mathrm{C}_{4} \mathrm{C}_{1} \mathrm{Im}\right]\left[\mathrm{NTf}_{2}\right]} \\
{\left[\mathrm{C}_{4} \mathrm{C}_{1} \mathrm{C}_{1} \mathrm{Im}\right]\left[\mathrm{NTf}_{2}\right]} \\
{\left[\mathrm{P}_{4,4,4,4}\right]\left[\mathrm{NTf}_{2}\right]} \\
{\left[\mathrm{P}_{4,4,4,4}\right]\left[\mathrm{NTf}_{2}\right]} \\
{\left[\mathrm{P}_{4,4,4,14}\right]\left[\mathrm{NTf}_{2}\right]} \\
{\left[\mathrm{P}_{4,4,4,14}\right][\mathrm{OTf}]} \\
{\left[\mathrm{P}_{4,4,4,14}\right]\left[\mathrm{PF}_{6}\right]} \\
{\left[\mathrm{P}_{4,4,4,414}\right][\mathrm{Cl}]} \\
\end{array}$ & & $\begin{array}{l}1.7 \pm 0.3 \\
1.9 \pm 0.4 \\
2.2 \pm 0.5 \\
1.9 \pm 0.4 \\
1.6 \pm 0.3 \\
1.4 \pm 0.3 \\
2.2 \pm 1.8 \\
5.0 \pm 1.3 \\
\end{array}$ & [77] \\
\hline$\left[\mathrm{CpRuCp} * \mathrm{RuCp}^{*}\right]\left[\mathrm{PF}_{6}\right]$ & $180^{\circ} \mathrm{C}, \mathrm{H}_{2}$ atmosphere & Yes & $\begin{array}{l}{\left[\mathrm{P}_{6,6,6,14}\right][\mathrm{DBS}]} \\
{\left[\mathrm{C}_{4} \mathrm{C}_{1} \mathrm{Im}\right]\left[\mathrm{PF}_{6}\right]}\end{array}$ & $\begin{array}{l}\text { Ethylene } \\
\text { Glycol }\end{array}$ & $\sim 2.5$ & {$[78,79]$} \\
\hline $\mathrm{RuO}_{2}$ & $75^{\circ} \mathrm{C}, \mathrm{H}_{2}$ (4 bar) & Yes & $\begin{array}{l}{\left[\mathrm{C}_{4} \mathrm{C}_{1} \mathrm{Im}\right]\left[\mathrm{PF}_{6}\right]} \\
{\left[\mathrm{C}_{4} \mathrm{C}_{1} \mathrm{Im}\right][\mathrm{OTf}]} \\
{\left[\mathrm{C}_{4} \mathrm{C}_{1} \mathrm{Im}\right]\left[\mathrm{BF}_{4}\right]}\end{array}$ & & $\begin{array}{l}2.5 \pm 0.4 \\
2.0 \pm 0.4\end{array}$ & $\begin{array}{l}{[55,56,} \\
89]\end{array}$ \\
\hline $\mathrm{RuCl}_{3}$ & $150^{\circ} \mathrm{C}, \mathrm{H}_{2}(1 \mathrm{bar})$ & Yes & [TMG][lactate] & SBA-15 & $2-5$ & [85] \\
\hline $\mathrm{Ru}_{3}(\mathrm{CO})_{12}$ & $\begin{array}{l}200^{\circ} \mathrm{C} \\
1000 \mathrm{~W} \text { UV } \\
\text { Microwave }\end{array}$ & Yes & {$\left[\mathrm{C}_{4} \mathrm{C}_{1} \mathrm{Im}\right]\left[\mathrm{BF}_{4}\right]$} & & $\begin{array}{l}1.6 \pm 0.4 \\
2.0 \pm 0.5 \\
1.6 \pm 0.3\end{array}$ & {$[80-83]$} \\
\hline
\end{tabular}

$\mathrm{COD}=$ cyclooctadiene, COT $=$ cyclooctatriene, $\mathrm{MA}=2$-methylallyl, $\mathrm{Cp}=$ cyclopentadienyl, $\mathrm{Cp}^{*}=$ pentamethylcyclopentadienyl, $\mathrm{C}_{1}, \mathrm{C}_{2}$, $\mathrm{C}_{4}$, etc. $=$ methyl, ethyl, butyl etc., Im = imidazolium, $\mathrm{P}_{6,6,6,14}=$ tri(hexyl)tetradecylphosphonium, TMG $=1,1,3,3$-tetramethylguanadinium, $\mathrm{OTf}=$ trifluoromethylsulfonate, $\mathrm{NTf}_{2}=$ bis $($ trifluoromethylsulfonyl)imide, AcO = acetate, $\mathrm{DBS}=$ dodecylbenzenesulfonate, $\mathrm{HDA}=$ hexadecylamine, $\mathrm{OA}=$ octylamine.<smiles>[R]1CCCCC1</smiles>

A.

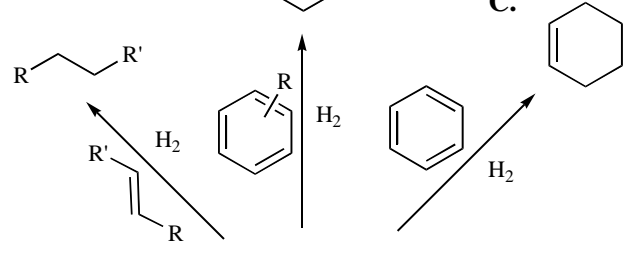

F.

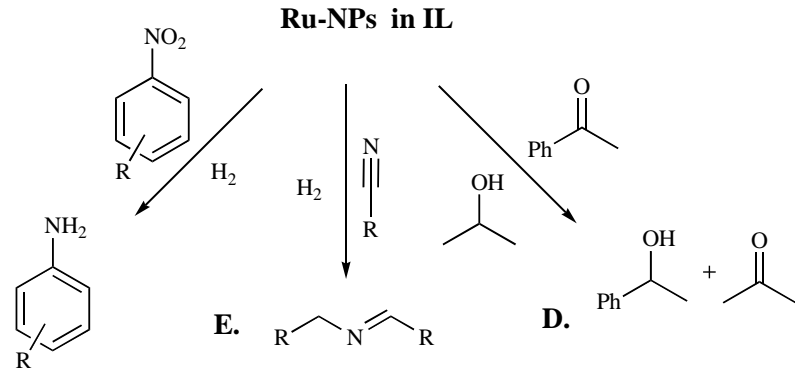

Scheme 5. Hydrogenation of multiple bonds with Ru-NPs in ILs (References see Table 2).

C-O bond cleavage [92, 98], hydrogenolysis [99], amminolysis [88], isotope exchange [79], C-H activation [100], as well as many energy-related applications (Fischer-Tropsch Synthesis) [101], Direct Methanol Fuel Cells (DMFC) [102, 103] and in general for biomass conversion [76, 78, 92, 97-99]. Ru-NPs usually act typically in heterogeneous reactions as solid state catalyst [90]. As discussed in the previous section, the ILs act as stabilising agents for the small-sized and mono-dispersed Ru-NPs to prevent agglomeration to bulk metal $[74,75,88]$. Moreover, the IL forms a protective layer to avoid oxidation of the sensitive and highly catalytic active metal surface [90]. The main advantage of these multiphase systems, with the Ru-NPs immobilised in the IL, is that they are easily recyclable by simple phase separation of the molecular organic phase containing the substrates and product, from the ionic catalytic solution [104]. Usually the catalytic phase does not show significant loss in activity. However, general limitations for metal nanoparticle catalysis are (I) metal leaching during phase separation $[105,106]$, (II) extraction of organic molecules into the IL-layer and vice-versa [107], and (III) slow mass transfer in the multiphase system due the relatively high viscosity, hence low hydrogen gas solubility [108].

\subsection{Hydrogenation Reactions}

Ruthenium NPs in ILs are highly active and recyclable catalysts for reduction reactions with hydrogen in multiphase systems, where several multiple bonds and functional groups are reactive in presence of gaseous hydrogen or under transfer-hydrogenation conditions (Scheme 5, Table 2, References see Table 2).

As previously discussed, ILs provide the opportunity to precisely control the size of Ru-NPs produced in situ, and thus this fact was used to investigate the effect of small changes in size of $\mathrm{Ru}-$ NPs on the activity and selectivity in the hydrogenation of cyclohexadiene [60]. In this study it was shown that with large size particles $(3 \mathrm{~nm})$ hydrogenation activity was increased, whereas smaller Ru-NPs $(1 \mathrm{~nm})$ favoured partially hydrogenated products. These findings could be attributed to the possible coordination modes of the substrate on different size Ru-NPs as shown in (Fig. 6). On smaller Ru-NPs, there exist no large open facets for the favoured planar coordination of the substrate and as such the reaction proceeds slower and rapid consecutive hydrogenation of both unsaturations is unlikely. Due their immiscibility in the IL phase, the hydrogenated products were separated, contributing to the high selectivity observed.

Some examples for catalyst-recycling in batch reactions show the promising potential for their recyclability without significant loss of catalyst activity (Table 2: Entry A) [55-57, 81]. It is impor- 

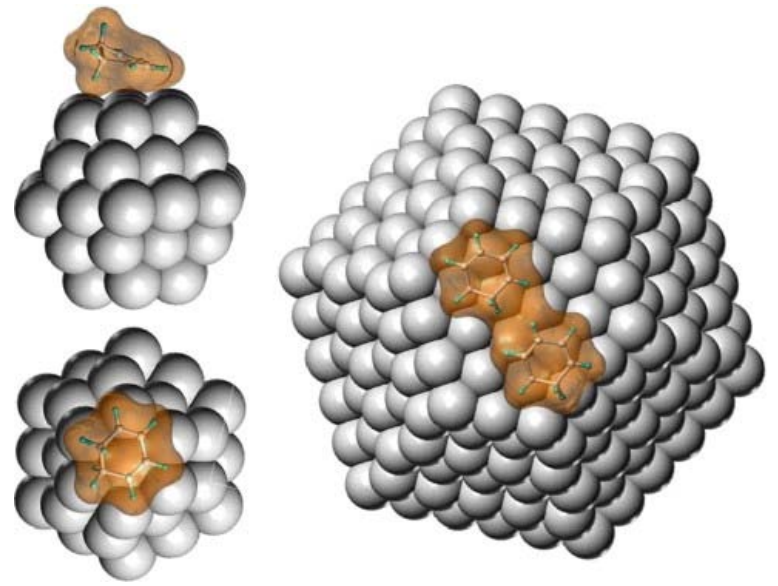

Fig. (6). Molecular models to illustrate the possible coordination of cycohexadiene on Ru-NPs of $1 \mathrm{~nm}$ (left) and $3 \mathrm{~nm}$ (right) [60] (Copyright Elsevier 2010).

tant to note that the stability of NPs is superior in ILs in comparison to NPs under solventless conditions. As previously mentioned, certain hydrocarbons can be extracted with ILs and vice versa [107]. Therefore, the protective IL-layer can be withdrawn from the NPs-surface, which may provoke the particle growth process leading to bulk metal accompanied by decreasing activity, due to the lack of available catalytic surface. Moreover, the selectivity can be influenced by the choice of IL. For example, nitriles are converted into imines whereas arene moieties remain stable in presence of nitrile-functionalised IL (Table 2: Entry: E) [88]. In the absence of nitriles, arenes are converted into the corresponding cycloalkanes (Table 2: Entry B) [74]. Also observed, the reduction of functional groups like ketones or nitro moieties results with high selectivity in the formation of the corresponding alcohols and anilines. (Table 2: Entry D and F) [95, 96]. Another example for selective hydrogenation is the highly interesting conversion of benzene to cyclohexene in the presence of Ru-NPs in $\left[\mathrm{C}_{4} \mathrm{C}_{1} \mathrm{Im}\right]\left[\mathrm{PF}_{6}\right]$ (Table 2: Entry C, Fig. 7) $[57,93]$. Moreover, Ru-NPs in ILs are suitable for the hydrogenation of biomass-derived organic molecules based on 5hydroxymethylfurfural (HMF) and furfural, which can be obtained in turn from hexoses and pentoses (Scheme 6) [76].

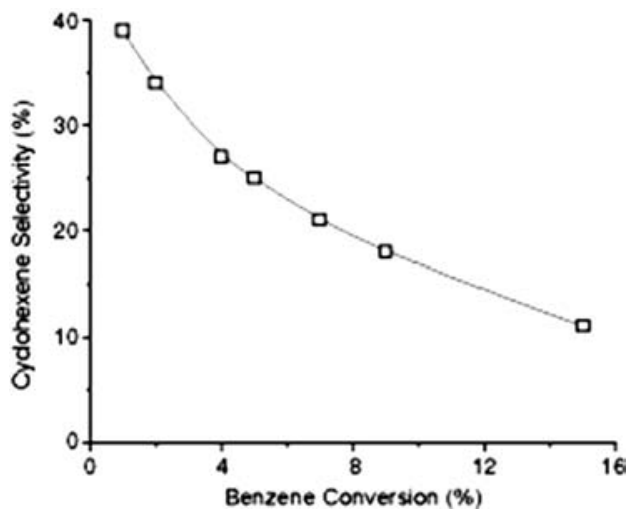

Fig. (7). Cyclohexene selectivity in the hydrogenation of benzene by $\mathrm{Ru}-$ NPs in $\left[\mathrm{C}_{4} \mathrm{C}_{1} \mathrm{Im}\right]\left[\mathrm{PF}_{6}\right]$ [57]. (Copyright Wiley Interscience 2004).

\subsection{Hydrogenolysis, Hydrodeoxygenation, Fragmentation and Amminolysis}

In recent years, Ru-NPs in ILs have been evaluated as catalytic systems for bond forming and bond cleavage reactions, in particular<smiles>[R20]CC[C@H](C)C(=O)/C=C/c1ccco1</smiles>

Scheme 6. Hydrogenation of biomass-derived 4-(2-furyl)-3-butene-2-one with Ru nanoparticles.

Table 2. Selected examples for double and triple bond hydrogenation with recyclable Ru-NPs in ILs: Alkenes, arenes, ketones, nitriles and nitrobenzenes (Entries A-F refer to Scheme 5; Entry G refer Scheme 6)

\begin{tabular}{|c|c|c|c|c|c|c|c|c|}
\hline Entry & IL & $\begin{array}{l}\text { Educt/[M] } \\
(\mathrm{mol} / \mathrm{mol})\end{array}$ & Educt & Product & Conv. [\%] & $\begin{array}{l}\mathbf{t}[\mathbf{h}] / \\
\mathbf{T}\left[{ }^{\circ} \mathbf{C}\right]\end{array}$ & Runs & Ref. \\
\hline A & $\begin{array}{l}{\left[\mathrm{C}_{4} \mathrm{C}_{1} \mathrm{Im}\right]\left[\mathrm{BF}_{4}\right]} \\
{\left[\mathrm{C}_{4} \mathrm{C}_{1} \mathrm{Im}\right]\left[\mathrm{PF}_{6}\right]} \\
{\left[\mathrm{C}_{4} \mathrm{C}_{1} \mathrm{Im}\right][\mathrm{OTf}]}\end{array}$ & $\begin{array}{l}500, \\
667 \\
1108\end{array}$ & Olefin & Alkane & 100 & $\begin{array}{l}0.6 / 75 \\
0.7 / 75 \\
2-4 / 90\end{array}$ & $\begin{array}{l}8 ; \\
17 \\
7\end{array}$ & $\begin{array}{l}{[55-57,} \\
81]\end{array}$ \\
\hline B & $\begin{array}{l}{\left[\mathrm{C}_{10} \mathrm{C}_{1} \mathrm{Im}\right]} \\
{\left[\mathrm{NTf}_{2}\right]}\end{array}$ & 200 & Arene & Cyclohexane & 96 & $18 / 75$ & n. d. & [74] \\
\hline $\mathrm{C}$ & $\begin{array}{l}{\left[\mathrm{C}_{4} \mathrm{C}_{1} \mathrm{Im}\right]\left[\mathrm{PF}_{6}\right]} \\
{\left[\mathrm{C}_{4} \mathrm{Py}\right][\mathrm{DCA}]}\end{array}$ & 1500 & $\begin{array}{l}\text { Benzene } \\
\text { Benzene }\end{array}$ & $\begin{array}{l}\text { Cyclohexene } \\
\text { Cyclohexene }\end{array}$ & $\begin{array}{l}2(34)^{\mathrm{a}} \\
83(30)^{\mathrm{a}}\end{array}$ & $\begin{array}{l}1.2 / 75 \\
2 / 100\end{array}$ & $\begin{array}{l}\text { n. d. } \\
\text { n. d. }\end{array}$ & {$[57,93]$} \\
\hline $\mathrm{D}$ & Choline hydroxide & 12 & Ketone & alcohol & 95 & $6 / 85$ & 5 & [95] \\
\hline E & $\begin{array}{l}{\left[\mathrm{C}_{3} \mathrm{CNC}_{1} \mathrm{Im}\right]} \\
{\left[\mathrm{NTf}_{2}\right]}\end{array}$ & 137 & Nitrile & Imine & 70 & $18 / 90$ & 3 & [88] \\
\hline $\mathrm{F}$ & {$\left[\mathrm{C}_{4} \mathrm{C}_{1} \mathrm{Im}\right]\left[\mathrm{BF}_{4}\right]$} & $1428(7140)^{\mathrm{b}}$ & Nitro-benzenes & anilines & $>99$ & $4 / 70$ & 5 & [96] \\
\hline G & $\begin{array}{l}{\left[\mathrm{C}_{12} \mathrm{C}_{1} \mathrm{Im}\right]} \\
{\left[\mathrm{NTf}_{2}\right]}\end{array}$ & 100 & $\begin{array}{l}\text { 4-(2-furyl)-3- } \\
\text { butene-2-one }\end{array}$ & $\begin{array}{l}\text { 4-(2-furyl)-3- } \\
\text { butane-2-ol }\end{array}$ & $>99(\sim 70)$ & $6 / 120$ & 5 & [76] \\
\hline
\end{tabular}

Im: imidazolium, Py: Pyridinium, $\mathrm{C}_{1}, \mathrm{C}_{4}, \mathrm{C}_{10}$ etc.: methyl, butyl, decyl etc., $\mathrm{C}_{3} \mathrm{CN}$ : butyronitrile, $\mathrm{BF}_{4}$ : tetrafluoroborate, $\mathrm{PF}_{6}$ : hexafluorophosphate, OTf $=$ triflate, $\mathrm{NTf}_{2}=$ bis(trifluoromethylsulfonyl)imide, DCA = dicyanamide; ${ }^{a}$ Selectivity for cyclohexene; ${ }^{b}$ total ratio over five runs. 

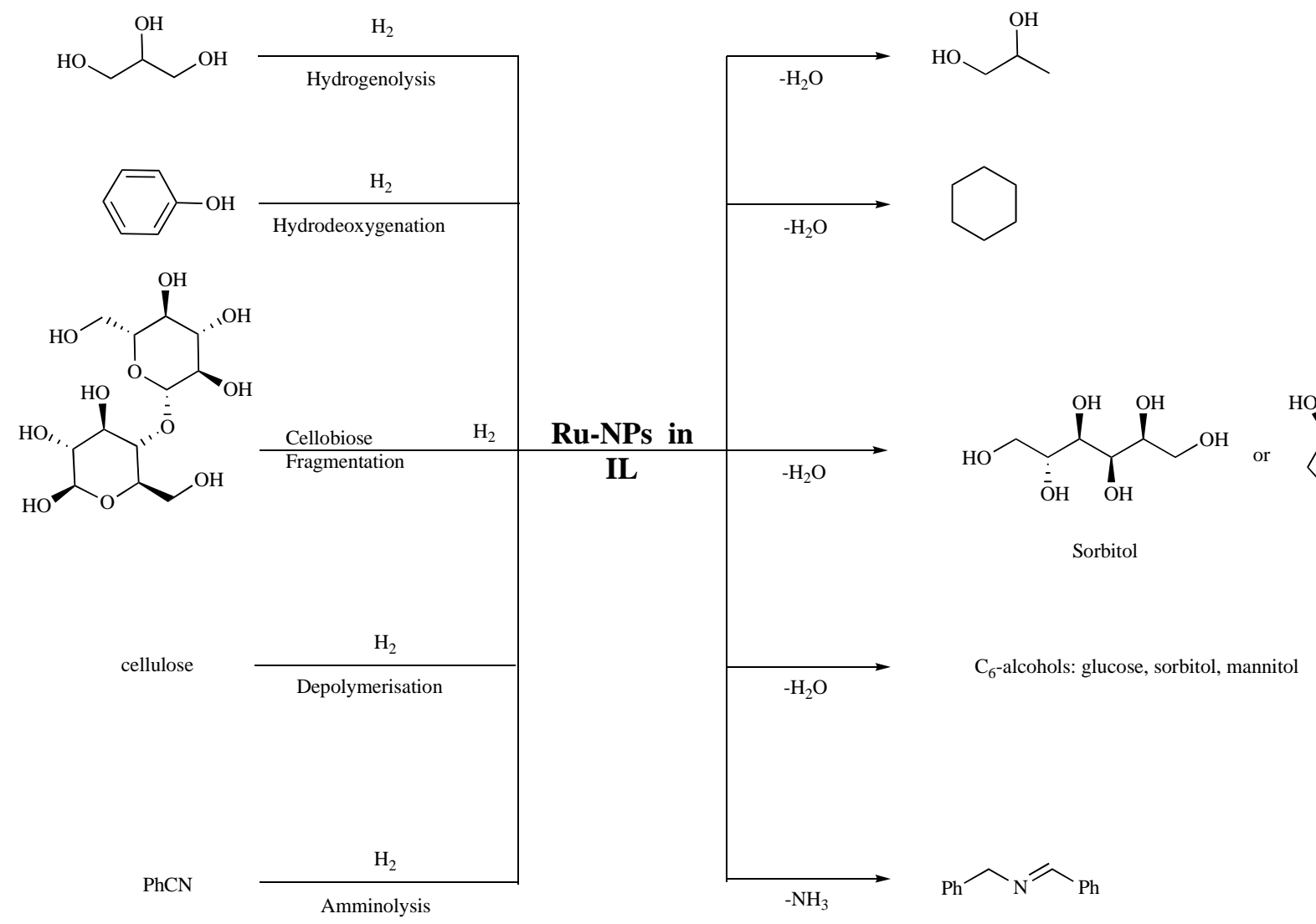

A.

B.

Scheme 7. Examples for defunctionalisation reactions in ILs promoted by Ru-NPs. (For references please refer the corresponding entries in Table 3)

for the conversion of biomass derived substrates. Examples of these include alcohols (glycerol), acetals (cellulose, cellobiose) and phenols, all of which it is desirable to further refine by hydrogenolysis, and/or hydrodeoxygenation (Scheme 7; Entries A-D) [78, 92, 9799]. Ru-NPs/IL catalyst-systems show some promising potential for recycling in batch experiments with high conversions $(>80 \%)$ and selectivities $(>80 \%)$ at least for the conversion of glycerol into 1,2propanediol in subsequent runs (Table 3: Entry A). For example, Jiang and Han et al. presented the hydrogenolysis of glycerol to 1,2-propanediol and ethylene glycol catalysed by $\mathrm{Ru} / \mathrm{Cu}$ bimetallic nanocatalysts [99]. These were immobilised on bentonite particles a composite-clay mainly consisting of $60 \% \mathrm{SiO}_{2}, 20 \% \mathrm{Al}_{2} \mathrm{O}_{3}, 4 \%$ $\mathrm{MgO}$ and $5 \% \mathrm{Na}_{2} \mathrm{O}$ - which were covered with the ionic liquid tetramethylguanidinium lactate ([TMG][lactate]). $\mathrm{RuCl}_{3}$ and $\mathrm{Cu}\left(\mathrm{NO}_{3}\right)_{2}$ were subsequently reduced in an aqueous solution of $\mathrm{NaBH}_{4}$. The hydrogenolysis of glycerol proceeded under 100 bars hydrogen, $230{ }^{\circ} \mathrm{C}$ within $10-18 \mathrm{~h}$, resulting in a liquid product mixture of mainly 1,2-propanediol (86\%) and ethylene glycol (9\%). The catalyst could be recycled 5 times without any loss of activity or selectivity. Moreover, the same reaction over nanoscale $\mathrm{Ru} / \mathrm{C}$ or $\mathrm{Ru} / \mathrm{TiO}_{2}$ catalysts impregnated with choline (2-hydroxy-N,N,Ntrimethylethanammonium) chloride can be performed with great success. At $100^{\circ} \mathrm{C}$ and with only 20 bars $\mathrm{H}_{2}$ pressure, about $30 \%$ of glycerol could be converted into 1,2-propanediol and ethylene glycol [109].

Dyson and Kou et al. presented the first successful conversion of cellobiose to smaller alcohols and monomeric sugars by hydrolysis and hydrogenation with the help of ruthenium nanoparticles (2.4 nm) [98]. Since, Maguire and co-workers have showed a chemical degradation of cellulose to hexitols (C6-sugars) as products. They used $\mathrm{Ru}$ nanoparticles in 1-(4'-(4"-(2"'-boronobenzyl)piperazinyl)- 2'-butenyl)-3-n-butylimidazolium chloride ([BBPBBIm][Cl]). The reaction takes place in presence of water with well dispersed nanoparticles under hydrogen. The major product was sorbitol with mannitol as the side-product. These polyalcohols are suitable for biofuel synthesis and display a possible pathway for biotransformation of cellulose to useful fine organic chemicals.

Another very interesting raw material for biofuel production is lignin. Alongside cellulose, lignin is one of the major components of wood and wood-like biomass and can be obtained by recycling waste materials from the wood-working industry. Up to now lignin, as a biopolymer consisting of several aromatic compounds, has to be depolymerised and hydrogenated, in order to synthesise the corresponding alcohols. Dyson and co-workers have presented a nanoparticle-based methodology to convert phenols into the corresponding cyclohexanes as a model reaction for the refinement of depolymerised lignin derivatives (Scheme 8) [97]. By use of acidic ionic liquids $\left[\mathrm{C}_{4} \mathrm{C}_{1} \mathrm{Im}\right]\left[\mathrm{NTf}_{2}\right]$ or $\left[\mathrm{C}_{4} \mathrm{C}_{1} \mathrm{Im}\right]\left[\mathrm{BF}_{4}\right]$ with in situ synthesised Ru-NPs, they were capable of hydrogenating phenol to cyclohexane with high conversions $(77 \%)$ and good selectivity $(98 \%)$. The reaction proceeds at $110-130^{\circ} \mathrm{C}$ in $4 \mathrm{~h}$ with hydrogen pressure of 40 bars.

The complete elimination of functional groups is often an undesirable side-reaction in organic synthesis, but on the other hand it is a possibility to for the recycling of environmental harmful compounds such as phenols. In biomass refinement, this process, known as hydrodeoxygenation, is very important as hydrocarbons containing less than $5 \mathrm{wt} \%$ oxygen are needed for fuel applications. For biomass feeds, oxygen content can be as high as $50 \%$. Some of the $\mathrm{O}$-containing compounds in the feed readily polymerise and cause thus poor fuel stability and performance during combustion [110]. 
Table 3. Examples for Defunctionalisation with Ru-NPs in ILs: hydrogenolysis, hydrodeoxygenation, cellulose/cellobiose fragmentation and amminolysis

\begin{tabular}{|c|c|c|c|c|c|c|c|c|}
\hline & Reaction & $\begin{array}{c}\text { Educt/[M] } \\
(\mathrm{mol} / \mathrm{mol})\end{array}$ & IL & Educt & Product & Conv. [\%] & Runs & Ref. \\
\hline A & Hydrogenolysis & $166^{\mathrm{a}}$ & [TMG][Lactate]-BEN & glycerol & 1,2-propanediol & 100 & 5 & [99] \\
\hline B & Hydro-deoxygenation & 300 & {$\left[\mathrm{C}_{4} \mathrm{C}_{1} \mathrm{Im}\right]\left[\mathrm{BF}_{4}\right]$} & Phenol & Cyclohexane & $77(97)^{b}$ & n. d. & [97] \\
\hline $\mathrm{C}$ & Cellobiose fragmentation & 10 & $\begin{array}{l}{\left[\mathrm{C}_{2} \mathrm{C}_{1} \mathrm{Im}\right]\left[\mathrm{NTf}_{2}\right] / \mathrm{H}_{2} \mathrm{O}} \\
{\left[\mathrm{C}_{2} \mathrm{C}_{1} \mathrm{Im}\right]\left[\mathrm{NTf}_{2}\right] /} \\
{\left[\mathrm{C}_{4} \mathrm{SO}_{3} \mathrm{C}_{4} \mathrm{Im}\right]\left[\mathrm{NTf}_{2}\right] \cdot \mathrm{HSO}_{4}}\end{array}$ & cellobiose & $\begin{array}{l}\text { Sorbitol } \\
\text { isosorbid }\end{array}$ & $\begin{array}{l}>99(94)^{\mathrm{b}} \\
>99(95)^{\mathrm{b}}\end{array}$ & n. d. & $\begin{array}{l}{[92]} \\
{[92]}\end{array}$ \\
\hline $\mathrm{D}$ & Cellulose fragmentation & $\begin{array}{l}146 \\
555^{\mathrm{c}}\end{array}$ & $\begin{array}{l}{\left[\mathrm{C}_{4} \mathrm{C}_{1} \mathrm{Im}\right][\mathrm{Cl}]} \\
{[\mathrm{BBPBBIm}][\mathrm{Cl}] /} \\
{\left[\mathrm{C}_{4} \mathrm{C}_{1} \mathrm{Im}\right][\mathrm{Cl}]}\end{array}$ & $\begin{array}{l}\text { cellulose } \\
\text { cellulose }\end{array}$ & $\begin{array}{l}\text { sorbitol } \\
\text { sorbitol }\end{array}$ & $\begin{array}{l}15 \\
94\end{array}$ & $\begin{array}{l}\text { n. d. } \\
\text { n. d. }\end{array}$ & $\begin{array}{l}{[98]} \\
{[78]}\end{array}$ \\
\hline E & Amminolysis & 137 & $\begin{array}{l}{\left[\mathrm{C}_{3} \mathrm{CNC}_{1} \mathrm{Im}\right]} \\
{\left[\mathrm{NTf}_{2}\right]} \\
{\left[\mathrm{C}_{4} \mathrm{C}_{1} \mathrm{Im}\right]\left[\mathrm{NTf}_{2}\right]}\end{array}$ & Nitrile & imine & 70 & 3 & {$[88]$} \\
\hline
\end{tabular}

$\mathrm{TMG}=1,1,3,3$-tetramethylguanidinium; BEN = bentonite; $\mathrm{C}_{4} \mathrm{SO}_{3} \mathrm{C}_{4} \mathrm{Im}=1$-(4-Butylsulfonic acid)-3-(n-butyl)-imidazolium; BBPBBIm = 1-(4'-(4"-(2"'-boronobenzyl)piperazinyl)2'-butenyl)-3-n-butylimidazolium; ${ }^{\mathrm{a}}$ bimetallic $\mathrm{Ru}-\mathrm{Cu}$ catalyst; ${ }^{\mathrm{b}}$ selectivity; ${ }^{\mathrm{c}}$ based on glucose-units in cellulose.

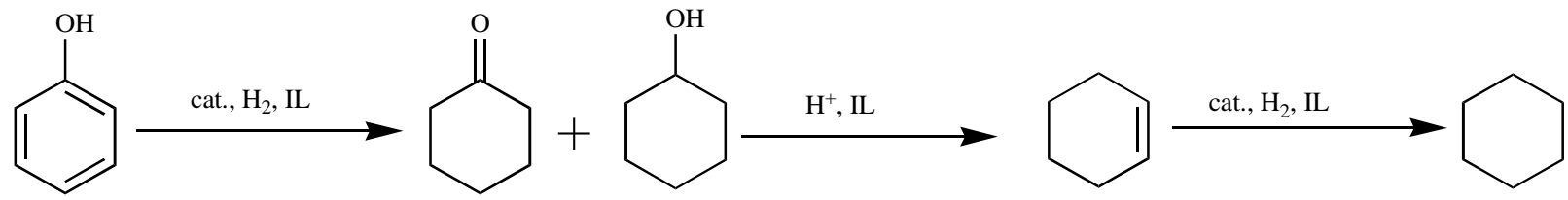

Scheme 8. Hydrodeoxygenation of phenols to cyclic alkanes with Ru nanoparticles in Brønsted acid-IL.

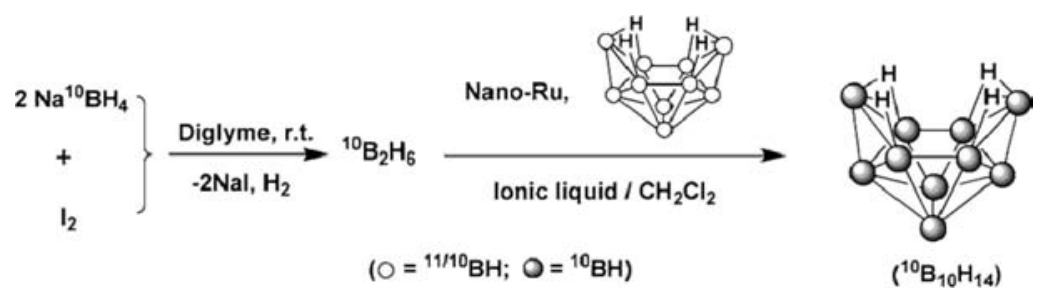

Fig. (8). Catalytic ${ }^{10} \mathrm{~B}-{ }^{11} \mathrm{~B}$ Isotope Exchange [79]. (Copyright American Chemical Society 2007)

In addition, $\mathrm{C}-\mathrm{O}$ bond cleavage reactions seem also suitable for the fragmentation of sugar-based biomass like cellulose or cellobiose, thus sugar monomers and bio-alcohol can be derived from renewable resources (Table 3: Entry C-D) [78, 92, 98].

\subsection{Isotope-Exchange with Ru-NPs in ILs}

Isotope exchange processes are methods for the analysis and characterisation of catalysts and are also of synthetic value. For example in the case of hydrogen isotopes, deuterated $\left(\mathrm{D},{ }^{2} \mathrm{H}\right)$ and tritiated $\left(\mathrm{T},{ }^{3} \mathrm{H}\right)$ compounds are used for NMR spectroscopy, as well as in pharmaceutical/medical research, e.g. for the investigation of metabolic processes of pharmaceutical products. Moreover, deuterated polymers have been tested in organic light emitting diodes (OLEDs) and are used in optical communication systems. Another clinical research example of the use of certain isotopes is in Boron neutron capture therapy (BNCT) where a ${ }^{10} \mathrm{~B}$-enriched boron compound is irradiated with low-energy neutrons yielding $\alpha$ particles and ${ }^{7} \mathrm{Li}$ nuclei [79]. BNCT has been focused for example on treatment of cerebral metastases of melanoma, and more recently, head, neck, and liver tumors [79]. Therefore, isotopelabelling as well as enrichment of isotopes is highly interesting for academic research as well as for application in industry and medicine. The ruthenium catalysed isotope exchange of boron atoms in decaborane is remarkable because several bonds are selectively broken and formed with a nanoscale catalyst without altering the nido-structure of the decaborane. Highly enriched ${ }^{10} \mathrm{~B}$-decaborane $\left(90 \%{ }^{10} \mathrm{~B}\right.$ and $97 \%$ conversion) can be obtained by repeated treatment (six times) of decaborane with ${ }^{10} \mathrm{~B}_{2} \mathrm{H}_{6}$ in presence of Ru-NPs (decaborane: $\mathrm{Ru}$ ratio $=20: 1$ ) in trihexyltetradecylphosphonium dodecylbenzenesulfonate ILs $\left(\left[\mathrm{P}_{6,6,6,14}\right][\mathrm{DBS}]\right)$, where the catalyst was recycled three times in batch experiments without significant loss in activity (Fig. 8) [79].

\subsection{Application of Ru-NPs in ILs for Energy related Catalysis Systems}

In the past few decades, there has been increasing interest in the development of clean power sources based on hydrogen, watersplitting or direct methanol fuel cells (DMFCs) and also for the synthetic fuel production in gas-to-liquid processes (GtL) such as Fischer-Tropsch-Synthesis. For the latter process, Ru-NPs protected with ILs have been successfully applied, and recyclability of the catalyst was achieved (Table 4: Entry 1) [101]. The product mixture included alkanes, olefins and oxygenated compounds in a range from $C_{5} / C_{7}$ to $C_{30}$ with selectivity as shown in (Fig. 9). Another field of application in the area of energy research involving Ru-NPs in ILs is their use as oxidation catalysts in fuel cells (Table 4: Entry 2) $[102,103]$. Here, the IL does not only take on the function of solvent and catalyst stabiliser, but also act as electrolyte. 
Table 4. Examples for energy and environment related systems with Ru-NPs in ILs: Fischer-Tropsch Synthesis, Fuel Cells, Hydrogen Generation / Storage

\begin{tabular}{|c|c|c|c|c|c|c|c|c|}
\hline No & Reaction & NPs & IL & Educt & Product & $\begin{array}{c}\text { Conv. } \\
{[\%]}\end{array}$ & Runs & Ref. \\
\hline 1 & Fischer-Tropsch & Ru & {$\left[\mathrm{C}_{4} \mathrm{C}_{1} \mathrm{Im}\right]\left[\mathrm{BF}_{4}\right]$} & $\mathrm{H}_{2} / \mathrm{CO}(2: 1)$ & $\mathrm{C}_{5}-\mathrm{C}_{30}$ & 75 & n.d. & [101] \\
\hline 2 & Oxidation (DMFC) & $\mathrm{Pt} / \mathrm{Ru}$ & {$\left[\mathrm{C}_{4} \mathrm{C}_{1} \mathrm{Im}\right]\left[\mathrm{BF}_{4}\right]$} & methanol & Energy / $\mathrm{CO}_{2}$ & 100 & 3 & $\begin{array}{r}{[102,} \\
103]\end{array}$ \\
\hline
\end{tabular}

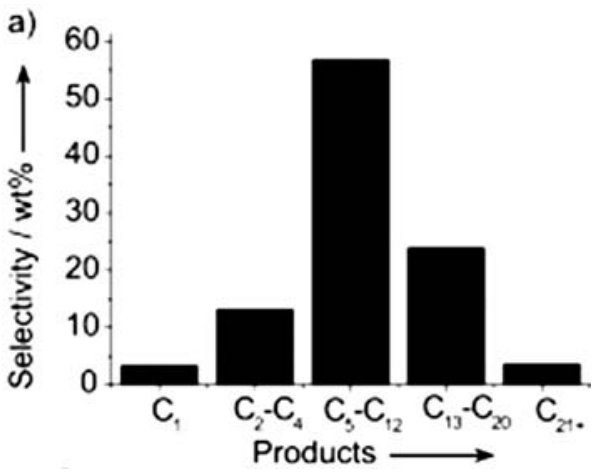

Fig. (9). Hydrocarbon selectivities for 2.0-nm-diameter ruthenium nanoclusters [101]. (Copyright Wiley Interscience 2008).

\subsection{Conclusion on Application in Catalysis}

Ru-NPs dispersed in ILs are recyclable catalysts for reactions in multiphase systems. The selectivity of these materials shows that they are suitable as multi-site catalysts. The Ru-NP/IL-systems often exhibit promising catalytic properties and long-term stability. In particular, the use of functionalised ILs shows that the stability and activity can be optimised with coordinating groups.

\section{FURTHER AND FUTURE APPLICATIONS}

Ruthenium nanoparticles from ionic liquids are not only proving to be versatile catalysts, but are also being developed for numerous other innovative applications. For example, a novel nonenzyme sensor for glucose detection in serum and urine samples and alcohol detection in blood has been developed with high potential for application. These are based on Ru-NPs or platinum and platinum-ruthenium nanoparticles, supported on multi-walled carbon nanotubes (MWNTs) in the presence of ILs [111, 112].

Another example is in novel electronic systems. Integrated circuits (ICs) are omnipresent in our everyday life (cell phones, cameras, computers, tablets, automotive, etc.) These objects need to become smarter and smarter, with increased miniaturization. For decades, this evolution was sustained by constant down-scaling of the circuitry, which is referred to as "Moore's law", in spite of increasingly complex technological challenges. However, the microelectronics industry is now progressing into a size range in which quantum effects are significant, and will soon reach the ultimate, physical limits of this approach. Other strategies are being explored to pursue device miniaturization. Among them, a promising approach consists in stacking several chips on top of each other to increase the complexity of the device without compromising its compactness [113-115]. In this architecture, a major challenge is the deposition of thin and continuous metallic layers in Through Silicon Vias (TSVs), the vertical holes interconnecting neighbouring levels. Indeed, the PVD-based processes currently used for this purpose suffer from limited step coverage, causing weaknesses, and even discontinuities in the metallic films on the features sidewalls. Hence, a more conformal deposition technique is desired. Moreover, this alternative solution should produce the liners with reduced cost. Recently, results on the formation of metallic films by annealing of silica supported Cu NPs [116] and Ag [117] have been reported. ILs are ideal media to synthesise such metallic NPs, as they act in the process both as solvent and stabiliser [13]. Furthermore, their relatively high thermal stability and low volatility are compatible with annealing conditions needed to achieve sintering of NPs and film formation. Thus, the full process flow including NPs synthesis, application on a substrate and film formation by thermal treatment could be conducted in the same medium, enabling simpler and shorter process, with reduced cost and limited oxidation of the metal. In this perspective, the use of suspensions of metallic NPs in ILs could be a real breakthrough for the fabrication of TSV $s$ [118].

Suspensions of Ru-NPs in ILs could find other applications in microelectronics processes or devices incorporating NPs. In addition to their ease of use, these suspensions would lead to superior results, due to the narrow size distribution of NPs. This size control could even be further enhanced by synthesising bimetallic nanoparticles, as was shown in the case of the $\mathrm{Ru}-\mathrm{Cu}$ system [119], such metallic NPs would be able to catalyse in-situ the synthesis of carbon nanotubes with controlled diameter and structure, envisioned as possible candidates to replace $\mathrm{Cu}$ interconnects [120].

They could also be used to form more reliable flash memory cells. In these devices, information is stored as an electric charge in a solid floating gate. In conventional cells, this information can be lost by charge leakage from this floating gate. Therefore, discrete floating gates are more reliable, since the cell remains functional even if one metallic particle loses its charge. Si NPs are already used for this purpose. However, metallic NPs such as Ru-NPs could store a larger quantity of charge, improving device performance [121].

\section{CONCLUSION}

As highly adaptable, charge-bearing, nano-structured liquids, ionic liquids present themselves as ideal media for the investigation of nanochemistry. They have been shown over the course of the last decade to be excellent media for the generation of metallic nanoparticles of small size and narrow size distributions. The ionic liquids offer a stabilisation to the NPs generated in situ, in such a way that no additional capping agents are required and the "ligand-free" NP surface is unhindered for catalysis. What's more, their tuneable miscibility properties may be utilised to drive the selectivity of a reaction, or to perform biphasic catalysis in order to limit catalyst leaching and separate more easily the products.

Herein we bring together in-depth studies performed on ruthenium nanoparticles in ionic liquids. The size of Ru-NPs can be highly controlled, by varying the adaptable IL or the experimental 
conditions, and this has been shown to be crucial in catalysis. Even the nature of the ionic liquid used may eventually lead to a different selectivity in certain reactions. Ru-NPs in ILs have shown to be versatile catalyst systems in reactions ranging from simple hydrogenations to energy related applications such as Fischer-Tropsch syntheses and biomass refinement.

Furthermore, these Ru-NPs-IL systems have been put to use in novel applications in diverse fields such as medical analysis where they can be used as glucose or alcohol detectors or microelectronics, where patents have been submitted for their use in the production of smarter devices.

It seems that this field, although already well developed, has much potential for yet further innovation. For example, by simply exploring the many other available ionic liquids could open the way to new and improved catalytic properties or smart materials.

\section{CONFLICT OF INTEREST}

The author(s) confirm that this article content has no conflicts of interest.

\section{ACKNOWLEDGEMENT}

Declared none.

\section{REFERENCES}

[1] Schmid, G., Nanoparticles: From Theory to Application. Wiley-VCH: Weinheim, 2004

[2] Bönnemann, H.; Nagabhushana, K. S., In Surface and Nanomolecular Catalysis, Richards, R. M., Ed. CRC Press: Boca Raton, 2006; pp 63-94.

[3] Astruc, D.; Lu, F.; Aranzaes, J. R., Nanoparticles as Recyclable Catalysts: The Frontier Between Homogeneous and Heterogeneous Catalysis. Angew. Chem. Int. Ed. 2005, 44, 7852 .

[4] Astruc, D., Nanoparticles and Catalysis. Wiley-VCH: Weinheim, 2007.

[5] Roucoux, A.; Schulz, J.; Patin, H., Reduced transition metal colloids: A novel family of reusable catalysts? Chem. Rev. 2002, 102, 3757-3778.

[6] Roucoux, A.; Nowicki, A.; Philippot, K., In Nanoparticles and Catalysis, Astruc, D., Ed. Wiley-VCH: Weinheim, 2007; pp 349-390.

[7] Roucoux, A.; Philippot, K., In Handbook of Homogeneous Hydrogenation, Vries, J. G. d.; Elsevier, C. J., Eds. Wiley-VCH: Weinheim, 2007; pp $217-$ 256.

[8] Valden, M.; Lai, X.; Goodman, D. W., Onset of Catalytic Activity of Gold Clusters on Titania with the Appearance of Nonmetallic Properties. Science 1998, 281, 1647.

[9] Bell, A. T., The Impact of Nanoscience on Heterogeneous Catalysis. Science 2003, 299, $1688-1691$

[10] Bönnemann, H.; Nagabhushana, K. S., In Metal Nanoclusters in Catalysis and Materials Science: The Issue of Size-control, Corain, B.; Schmid, G.; Toshima, N., Eds. Elsevier: Amsterdam, 2007; pp 21-48.

[11] Chaudret, B., Synthesis and Surface Reactivity of Organometallic Nanoparticles. Top. Organomet. Chem. 2005, 16, 233-259.

[12] Amiens, C.; Chaudret, B., Organometallic synthesis of nanoparticles. Mod. Phys. Lett. B 2007, 21, 1133-1141.

[13] Dupont, J.; Scholten, J. D., On the structural and surface properties of transition-metal nanoparticles in ionic liquids. Chem. Soc. Rev. 2010, 39, 17801804

[14] Scholten, J. D.; Leal, C. B.; Dupont, J., Transition Metal Nanoparticle Catalysis in Ionic Liquids. ACS Catalysis 2012, 2, 184-200.

[15] Wasserscheid, P.; Welton, T., Ionic Liquids in Synthesis. Wiley-VCH: Weinheim, 2007.

[16] Welton, T., Room-temperature ionic liquids. Solvents for synthesis and catalysis. Chem. Rev. 1999, 99, 2071.

[17] Welton, T., Ionic liquids in catalysis. Coordination Chemistry Reviews 2004, 248, 2459-2477.

[18] Hallett, J. P.; Welton, T., Room-temperature ionic liquids: Solvents for synthesis and catalysis. Chem. Rev. 2011, 111, 3508-3576.

[19] Canongia Lopes, J. N.; Padua, A. A. H., Nanostructural Organization in Ionic Liquids. J. Phys. Chem. B. 2006, 110, 3330-3335.

[20] Wang, Y.; Izvekov, S.; Yan, T.; Voth, G. A., Multiscale Coarse-Graining of Ionic Liquids. J. Phys. Chem. B 2006, 110, 3564-3575.

[21] Gutel, T.; Santini, C. C.; Philippot, K.; Padua, A.; Pelzer, K.; Chaudret, B.; Chauvin, Y.; Basset, J. M., Organized 3D-alkyl imidazolium ionic liquids could be used to control the size of in situ generated ruthenium nanoparticles? J. Mater. Chem. 2009, 19, 3624-3631.
[22] Bruneau, C.; Dixneuf, P. H., Ruthenium Catalysts and Fine Chemistry. Springer: Berlin/ Heidelberg, 2004

[23] Vougioukalakis, G. C.; Grubbs, R. H., Ruthenium-based heterocyclic carbene-coordinated olefin metathesis catalysts. Chem. Rev. 2010, 110, 17461787.

[24] Nagahara, H.; Ono, M.; Konishi, M.; Fukuoka, Y., Partial hydrogenation of benzene to cyclohexene. Appl. Surf. Sci. 1997, 121, 448-451.

[25] Galletti, A. M. R.; Antonetti, S.; Giaiacopi, S.; Piccolo, O.; Venzia, A. M., Innovative Process for the Synthesis of Nanostructured Ruthenium Catalysts and their Catalytic Performance. Top. Catal. 2009, 52, 1065.

[26] Miyazaki, A.; Balint, L.; Aika, K.; Nakano, Y., Preparation of Ru Nanoparticles Supported on $\gamma$-Al2O3 and Its Novel Catalytic Activity for Ammonia Synthesis. J. Catal. 2001, 204, 364-371.

[27] Schlögl, R., Catalytic synthesis of ammonia - A "never-ending story"? Angew. Chem. Int. Ed. 2003, 42, 2004-2008.

[28] Theolier, A.; Choplin, A.; D'Ornelas, L.; Basset, J. M., The characterization and thermal stability of a cluster Polyhedron 1983, 2, 119-121.

[29] Kuznetsov, V. L.; Bell, A. T.; Yermakov, Y. I., An infrared study of alumina- and silica-supported ruthenium cluster carbonyls. J. Catal. 1980, 65, 374-389.

[30] Zecchina, A.; Guglielminotti, E.; Bossi, A.; Camia, M., Surface characterization of the Ru3(CO) $12 \mathrm{Al} 2 \mathrm{O} 3$ system: I. Interaction with the hydroxylated surface. J. Catal. 1982, 74, 225-239.

[31] Bianchini, C.; Santo, V. D.; Meli, A.; Moneti, S.; Moreno, M.; Oberhauser, W.; Psaro, R.; Sordelli, L.; Vizza, F., A comparison between silicaimmobilised ruthenium(II) single sites and silica-supported ruthenium nanoparticles in the catalytic hydrogenation of model hetero- and polyaromatics contained in raw oil materials $J$. Catal. 2003, 213, 47-62.

[32] Basset, J. M.; Choplin, A., Surface organometallic chemistry: A new approach to heterogeneous Catalysis ? . J. Mol. Catal. A: Chem. 1983, 21, 95 108.

[33] Rodriguez, E.; Leconte, M.; Basset, J.-M.; Tanaka, K.; Tanaka, K.-I., Hydrogenolysis and homologation of linear and branched pentenes on ruthenium/silica catalysts: implication in the mechanism of carbon-carbon bond formation and cleavage on metal surfaces. J. Am. Chem. Soc. 1988, 110, 275278

[34] Leconte, M.; Theolier, A.; Rojas, D.; Basset, J. M., Stoichiometric and catalytic homologation of olefins on the Fischer-Tropsch catalysts $\mathrm{Fe} / \mathrm{SiO} / \mathrm{sub} 2 /, \mathrm{Ru} / \mathrm{SiO} /$ sub 2/, Os/SiO/sup 2/, and $\mathrm{Rh} / \mathrm{SiO} /$ sub 2/. Mechanistic implication in the mode of C-C bond formation. J. Am. Chem. Soc. 1984, 106, 1141-1142.

[35] Hulea, V.; Brunel, D.; Galarneau, A.; Philippot, K.; Chaudret, B.; Kooyman, P. J.; Fajula, F., Synthesis of well-dispersed ruthenium nanoparticles inside mesostructured porous silica under mild conditions. Microporous Mesoporous Mater. 2005, 79, 185-194.

[36] Moggi, P.; Albanesi, G.; Predieri, G.; Spoto, G., Ruthenium cluster-derived catalysts for ammonia synthesis. Appl. Catal., A 1995, 123, 145-159.

[37] Song, L.; Li, X.; Wang, H.; Wu, H.; Wu, P., Ru Nanoparticles Entrapped in Mesopolymers for Efficient Liquid-phase Hydrogenation of Unsaturated Compounds. Catal. Lett. 2009, 133, 63-69.

[38] Viau, G.; Brayner, R.; Poul, L.; Chakroune, N.; Lacaze, E.; Fievet-Vincent, F.; Fievet, F., Ruthenium Nanoparticles: Size, Shape, and Self-Assemblies. Chem. Mater. 2003, 15, 486-494.

[39] Joo, S. H.; Park, J. Y.; Renzas, J. R.; Butcher, D. R.; Huang, W.; Somorjai, G. A., Size Effect of Ruthenium Nanoparticles in Catalytic Carbon Monoxide Oxidation. Nano Lett. 2010, 10, 2709-2713.

[40] Yan, X. P.; Liu, H. F.; Liew, K. Y., Size control of polymer-stabilised ruthenium nanoparticles by polyol reduction. J. Mater. Chem. 2001, 11, 3387 3391 .

[41] Zawadzki, M.; Okal, J., Synthesis and structure characterization of Ru nanoparticles stabilised by PVP or $\gamma$-A12O3. Mater. Res. Bull. 2008, 43 , 3111-3121.

[42] Harpeness, R.; Peng, Z.; Liu, X. S.; Pol, V. G.; Koltypin, Y.; Gedanken, A., Controlling the agglomeration of anisotropic Ru nanoparticles by the microwave-polyol process J. Colloid Interface Sci. 2005, 287, 678-684.

[43] Lara, P.; Rivada-Wheelaghan, O.; Conejero, S.; Poteau, R.; Philippot, K Chaudret, B., Ruthenium Nanoparticles Stabilised by N-Heterocyclic Carbenes: Ligand Location and Influence on Reactivity. Angew. Chem., Int. Ed. 2011, 50, 12080-12084.

[44] Gual, A.; Axet, M. R.; Philippot, K.; Chaudret, B.; Denicourt-Nowicki, A. Roucoux, A.; Castillon, S.; Claver, C., Diphosphite ligands derived from carbohydrates as stabilisers for ruthenium nanoparticles: promising catalytic systems in arene hydrogenation. Chem. Commun. 2008, 2759-2761.

[45] Gual, A.; Godard, C.; Philippot, K.; Chaudret, B.; Denicourt-Nowicki, A.; Roucoux, A.; Castillon, S.; Claver, C., Carbohydrate-Derived 1,3 Diphosphite Ligands as Chiral Nanoparticle Stabilisers: Promising Catalytic Systems for Asymmetric Hydrogenation. Chemsuschem 2009, 2, 769-779.

[46] Zahmakiran, M.; Philippot, K.; Oezkar, S.; Chaudret, B., Size-controllable APTS stabilised ruthenium( 0 ) nanoparticles catalyst for the dehydrogenation of dimethylamine-borane at room temperature. Dalton Trans. 2012, 41, 590 598

[47] Bronger, R.; Le, T. D.; Bastin, S.; Garcia-Anton, J.; Citadelle, C.; Chaudret, B.; Lecante, P.; Igau, A.; Philippot, K., Multi-site coordination Nphosphanylamidine ligands as stabilisers for the synthesis of ruthenium nanoparticles. New J. Chem. 2011, 35, 2653-2660. 
[48] Hubert, C.; Denicourt-Nowicki, A.; Roucoux, A.; Landy, D.; Leger, B.; Crowyn, G.; Monflier, E., Catalytically active nanoparticles stabilised by host-guest inclusion complexes in water. Chem. Commun. 2009, 1228-1230.

[49] Nowicki, A.; Zhang, Y.; Leger, B.; Rolland, J.-P.; Bricout, H.; Monflier, E.; Roucoux, A., Supramolecular shuttle and protective agent: a multiple role of methylated cyclodextrins in the chemoselective hydrogenation of benzene derivatives with ruthenium nanoparticles. Chem. Commun. 2006, 296-298.

[50] Denicourt-Nowicki, A.; Roucoux, A.; Wyrwalski, F.; Kania, N.; Monflier, E.; Ponchel, A., Carbon-supported ruthenium nanoparticles stabilised by methylated cyclodextrins: a new family of heterogeneous catalysts for the gas-phase hydrogenation of arenes. Chem.--Eur. J. 2008, 14, 8090-8093.

[51] Lee, J. Y.; Yang, J.; Deivaraj, T. C.; Too, H. P., A novel synthesis route for ethylenediamine-protected ruthenium nanoparticles. J. Colloid Interface Sci. 2003, 268, 77-80.

[52] Yang, J.; Lee, J. Y.; Deivaraj, T. C.; Too, H. P., Preparation and characterization of positively charged ruthenium nanoparticles. J. Colloid Interface Sci. 2004, 271, 308-312.

[53] Yang, J.; Deivaraj, T. C.; Too, H. P.; Lee, J. Y., Acetate Stabilisation of Metal Nanoparticles and Its Role in the Preparation of Metal Nanoparticles in Ethylene Glycol. Langmuir 2004, 20, 4241-4245.

[54] Sanchez-Delgado, R. A.; Machalaba, N.; Ng-A-Qui, N., Hydrogenation of quinoline by ruthenium nanoparticles immobilised on poly(4-vinylpyridine). Catal. Commun. 2007, 8, 2115-2118.

[55] Rossi, L. M.; Dupont, J.; Machado, G.; Fichtner, P. F. P.; Radtke, C.; Baumvol, I. J. R.; Teixeira, Sr., Ruthenium dioxide nanoparticles in ionic liquids: Synthesis, characterization and catalytic properties in hydrogenation of olefins and arenes. J. Braz. Chem. Soc. 2004, 15, 904-910.

[56] Rossi, L. M.; Machado, G.; Fichtner, P. F. P.; Teixeira, S. R.; Dupont, J., On the use of ruthenium dioxide in 1-n-butyl-3-methylimidazolium ionic liquids as catalyst precursor for hydrogenation reactions. Catal. Lett. 2004, 92, 149155

[57] Silveira, E. T.; Umpierre, A. P.; Rossi, L. M.; Machado, G.; Morais, J.; Soares, G. V.; Baumvol, I. L. R.; Teixeira, S. R.; Fichtner, P. F. P.; Dupont, J., The partial hydrogenation of benzene to cyclohexene by nanoscale ruthenium catalysts in imidazolium ionic liquids. Chem.--Eur. J. 2004, 10, 37343740

[58] Gutel, T.; Garcia-Anton, J.; Pelzer, K.; Philippot, K.; Santini, C. C.; Chauvin, Y; Chaudret, B.; Basset, J.-M., Influence of the self-organization of ionic liquids on the size of ruthenium nanoparticles: effect of the temperature and stirring. J. Mater. Chem. 2007, 17, 3290-3292.

[59] Pelzer, K.; Vidoni, O.; Philippot, K.; Chaudret, B.; Colliere, V., Organometallic Synthesis of Size-Controlled Polycrystalline Ruthenium Nanoparticles in the Presence of Alcohols. Adv. Funct. Mater. 2003, 13, 118-126.

[60] Campbell, P. S.; Santini, C. C.; Bayard, F.; Chauvin, Y.; Colliere, V.; Podgorsek, A.; Gomes, M. F. C.; Sa, J., Olefin hydrogenation by ruthenium nanoparticles in ionic liquid media: Does size matter? J. Catal. 2010, 275, 99-107.

[61] Triolo, A.; Russina, O.; Bleif, H.-J.; Cola, E. D., J. Phys. Chem. B 2007, 111, 4641-4644.

[62] Gutel, T. Les liquides ioniques, leur utilisation et leur role comme solvants de réaction catalytique. Ph. D. Thesis, Université Claude Bernard Lyon 1, Lyon, 2007.

[63] Campbell, P. S.; Santini, C. C.; Bouchu, D.; Fenet, B.; Philippot, K.; Chaudret, B.; Padua, A. A. H.; Chauvin, Y., A novel stabilisation model for ruthenium nanoparticles in imidazolium ionic liquids: in situ spectroscopic and labelling evidence. Phys. Chem. Chem. Phys. 2010, 12, 4217-4223.

[64] Pery, T.; Pelzer, K.; Buntkowsky, G.; Philippot, K.; Limbach, H.-H.; Chaudret, B., Direct NMR Evidence for the Presence of Mobile Surface Hydrides on Ruthenium Nanoparticles. ChemPhysChem 2005, 6, 605-607.

[65] Berthoud, R.; Delichere, P.; Gajan, D.; Lukens, W.; Pelzer, K.; Basset, J.-M.; Candy, J.-P.; Coperet, C., Hydrogen and oxygen adsorption stoichiometries on silica supported ruthenium nanoparticles. J. Catal. 2008, 260, 387-391.

[66] Okal, J., Characterization and thermal stability of ruthenium nanoparticles supported on $\gamma$-alumina. Catal. Commun. 2010, 11, 508-512.

[67] Ott, L. S.; Finke, R. G., Transition-metal nanocluster stabilisation for catalysis: A critical review of ranking methods and putative stabilisers. Coord. Chem. Rev. 2007, 251, 1075-1100.

[68] Ott, L. S.; Finke, R. G., Nanocluster Formation and Stabilisation Fundamental Studies: $†$ Investigating "Solvent-Only" Stabilisation En Route to Discovering Stabilisation by the Traditionally Weakly Coordinating Anion BF4Plus High Dielectric Constant Solvents. Inorg. Chem. 2006, 45, 8382-8393.

[69] Oezkar, S.; Finke, R. G., J. Am. Chem. Soc. 2002, 124, 5796-5810.

[70] Umpierre, A. P.; Machado, G.; Fecher, G. H.; Morais, J.; Dupont, J., Selective Hydrogenation of 1,3-Butadiene to 1-Butene by $\operatorname{Pd}(0)$ Nanoparticles Embedded in Imidazolium Ionic Liquids. Adv. Synth. Catal. 2005, 347, 1404-1412.

[71] Dupont, J.; Silva, D. D. O., In Nanoparticles \& Catalysis, Astruc, D., Ed. Wiley-VCH: Weinheim, 2008.

[72] Bönnemann, H.; Nagabhushana, K. S.; Richards., R. M., In Nanoparticles \& Catalysis, Astruc, D., Ed. Wiley-VCH: Weinheim, 2008.

[73] Campbell, P. S. Utilising the solvation properties of ionic liquids in the sizecontrolled synthesis and stabilisation of metal nanoparticles for catalysis in situ. Ph.D., Université Claude Bernard Lyon 1, Lyon, 2010.
[74] Prechtl, M. H. G.; Scariot, M.; Scholten, J. D.; Machado, G.; Teixeira, S. R. Dupont, J., Nanoscale $\mathrm{Ru}(0)$ particles: Arene hydrogenation catalysts in imidazolium ionic liquids. Inorg. Chem. 2008, 47, 8995-9001.

[75] Prechtl, M. H. G.; Campbell, P. S ; Scholten, J. D.; Fraser, G. B * Machado, G.; Santini, C. C.; Dupont, J.; Chauvin, Y., Imidazolium ionic liquids as promoters and stabilising agents for the preparation of metal $(0)$ nanoparticles by reduction and decomposition of organometallic complexes. Nanoscale 2010, 2, 2601-2606.

[76] Julis, J.; Holscher, M.; Leitner, W., Selective hydrogenation of biomass derived substrates using ionic liquid-stabilised ruthenium nanoparticles. Green Chem. 2010, 12, 1634-1639.

[77] Luska, K. L.; Moores, A., Ruthenium nanoparticle catalysts stabilised in phosphonium and imidazolium ionic liquids: dependence of catalyst stability and activity on the ionicity of the ionic liquid. Green Chem. 2012, 14, 1736.

[78] Zhu, Y. H.; Kong, Z. N.; Stubbs, L. P.; Lin, H.; Shen, S. C.; Anslyn, E. V.; Maguire, J. A., Conversion of Cellulose to Hexitols Catalysed by Ionic Liquid-Stabilised Ruthenium Nanoparticles and a Reversible Binding Agent. Chemsuschem 2010, 3, 67-70.

[79] Zhu, Y. H.; Widjaja, E.; Sia, S. L. P.; Zhan, W.; Carpenter, K.; Maguire, J. A.; Hosmane, N. S.; Hawthorne, M. F., Ruthenium(0) nanoparticle-catalysed isotope exchange between B-10 and B-11 nuclei in decaborane(14). J. Am. Chem. Soc. 2007, 129, 6507-6512.

[80] Kramer, J.; Redel, E.; Thomann, R.; Janiak, C., Use of ionic liquids for the synthesis of iron, ruthenium, and osmium nanoparticles from their metal carbonyl precursors. Organometallics 2008, 27, 1976-1978.

[81] Vollmer, C.; Redel, E.; Abu-Shandi, K.; Thomann, R.; Manyar, H.; Har dacre, C.; Janiak, C., Microwave Irradiation for the Facile Synthesis of Transition-Metal Nanoparticles (NPs) in Ionic Liquids (ILs) from Metal-Carbonyl Precursors and Ru-, Rh-, and Ir-NP/IL Dispersions as Biphasic LiquidLiquid Hydrogenation Nanocatalysts for Cyclohexene. Chem.--Eur. J. 2010, 16, 3849-3858, S3849/1-S3849/34

[82] Janiak, C.; Redel, E.; Klingele, M.; Schubert, T.; Beyersdorff, T. Method for the production and stabilisation of functional metal nanoparticles in ionic liquids. 2008-EP6768 2009024312, 20080818., 2009.

[83] Vollmer, C.; Janiak, C., Naked metal nanoparticles from metal carbonyls in ionic liquids: Easy synthesis and stabilisation. Coord. Chem. Rev. 2011, 255, 2039-2057.

[84] Marquardt, D; Vollmer, C.; Thomann, R.; Steurer, P.; Mulhaupt, R.; Redel, E.; Janiak, C., The use of microwave irradiation for the easy synthesis of graphene-supported transition metal nanoparticles in ionic liquids. Carbon 2011, 49, 1326-1332.

[85] Huang, J; Jiang, T; Han, B.; Wu, W.; Liu, Z; Xie, Z; Zhang, J., A Novel Method to Immobilise Ru Nanoparticles on SBA-15 Firmly by Ionic Liquid and Hydrogenation of Arenes. Catal. Lett. 2005, 103, 59-62.

[86] Salas, G.; Santini, C. C.; Philippot, K.; Colliere, V.; Chaudret, B.; Fenet, B. Fazzini, P. F., Influence of amines on the size control of in situ synthesised ruthenium nanoparticles in imidazolium ionic liquids. Dalton Trans. 2011 40, 4660-4668

[87] Salas, G.; Podgorsek, A.; Campbell, P. S.; Santini, C. C.; Padua, A. A. H.; Gomes, M. F. C.; Philippot, K.; Chaudret, B.; Turmine, M., Ruthenium nanoparticles in ionic liquids: structural and stability effects of polar solutes Phys. Chem. Chem. Phys. 2011, 13, 13527-13536.

[88] Prechtl, M. H. G.; Scholten, J. D.; Dupont, J., Tuning the selectivity of ruthenium nanoscale catalysts with functionalised ionic liquids: Hydrogenation of nitriles. J. Mol. Catal. A: Chem. 2009, 313, 74-78.

[89] Rossi, L. M.; Machado, G., Ruthenium nanoparticles prepared from ruthenium dioxide precursor: Highly active catalyst for hydrogenation of arenes under mild conditions. J. Mol. Catal. A: Chem. 2009, 298, 69-73.

[90] Migowski, P.; Dupont, J., Catalytic applications of metal nanoparticles in imidazolium ionic liquids. Chem.--Eur. J. 2007, 13, 32-39.

[91] Geilen, F. M. A.; vom Stein, T.; Engendahl, B.; Winterle, S.; Liauw, M. A.; Klankermayer, J.; Leitner, W., Highly Selective Decarbonylation of 5(Hydroxymethyl)furfural in the Presence of Compressed Carbon Dioxide. Angew. Chem., Int. Ed. 2011, 50, 6831-6834, S6831/1-S6831/6.

[92] Liauw, M. A.; Winterle, S., Catalytic conversion of cellobiose. Chem. Ing. Tech. 82, 1211-1214.

[93] Schwab, F.; Lucas, M.; Claus, P., Ruthenium-Catalysed Selective Hydrogenation of Benzene to Cyclohexene in the Presence of an Ionic Liquid. Angewandte Chemie-International Edition 2011, 50, 10453-10456.

[94] Zahmakiran, M.; Ozkar, S., Metal nanoparticles in liquid phase catalysis; from recent advances to future goals. Nanoscale 2011, 3, 3462-3481.

[95] Kantam, M. L.; Reddy, R. S.; Pal, U.; Sreedhar, B.; Bhargava, S., Transfer Hydrogenation of Carbonyl Compounds Catalysed by Ruthenium Nanoparticles Stabilised on Nanocrystalline Magnesium Oxide by Ionic Liquids. Adv. Synth. Catal. 2008, 350, 2231-2235.

[96] Cui, X. J.; Shi, F; Deng, Y. Q., Ionic Liquid Templated Preparation of $\mathrm{Ru} / \mathrm{SiO} 2$ and Its Activity in Nitrobenzene Hydrogenation. Chemcatchem 2012, 4, 333-336.

[97] Yan, N.; Yuan, Y.; Dykeman, R.; Kou, Y.; Dyson, P. J., Hydrodeoxygenation of Lignin-Derived Phenols into Alkanes by Using Nanoparticle Catalysts Combined with Bronsted Acidic Ionic Liquids. Angew. Chem., Int. Ed. 2010, 49, 5549-5553, S5549/1-S5549/13

[98] Yan, N.; Zhao, C.; Luo, C.; Dyson, P. J.; Liu, H.; Kou, Y., One-Step Conversion of Cellobiose to C6-Alcohols Using a Ruthenium Nanocluster Catalyst. J. Am. Chem. Soc. 2006, 128, 8714-8715. 
[99] Jiang, T.; Zhou, Y. X.; Liang, S. G.; Liu, H. Z.; Han, B. X., Hydrogenolysis of glycerol catalysed by Ru-Cu bimetallic catalysts supported on clay with the aid of ionic liquids. Green Chem. 2009, 11, 1000-1006.

[100] Biletzki, T.; Stark, A.; Imhof, W., Ionic liquids as solvents for a rutheniumcatalysed C-H activation reaction: synthesis of heterocyclic compounds from alpha,beta-unsaturated imines, carbon monoxide, and ethylene. Monatsh. Chem. 2010, 141, 413-418.

[101] Xiao, C. X.; Cai, Z. P.; Wang, T.; Kou, Y.; Yan, N., Aqueous-phase FischerTropsch synthesis with a ruthenium nanocluster catalyst. Angew. Chem. Int. Ed. 2008, 47, 746-749.

[102] Xue, X.; Liu, C.; Lu, T.; Xing, W., Synthesis and characterization of Pt/C nanocatalysts using room temperature ionic liquids for fuel cell applications. Fuel Cells 2006, 6, 347-355.

[103] Xue, X. Z; Lu, T. H; Liu, C. P; Xu, W. L; Su, Y; Lv, Y. Z; Xing, W. Novel preparation method of $\mathrm{Pt}-\mathrm{Ru} / \mathrm{C}$ catalyst using imidazolium ionic liquid as solvent. Electrochim. Acta 2005, 50, 3470-3478.

[104] Dupont, J.; de Souza, R. F.; Suarez, P. A. Z., Ionic liquid (molten salt) phase organometallic catalysis. Chem Rev 2002, 102, 3667-3691.

[105] Consorti, C. S.; Flores, F. R.; Dupont, J., Kinetics and mechanistic aspects of the Heck reaction promoted by a CN-palladacycle. J. Am. Chem. Soc. 2005, 127, 12054-12065.

[106] Cassol, C. C.; Umpierre, A. P.; Machado, G.; Wolke, S. I.; Dupont, J., The role of Pd nanoparticles in ionic liquid in the Heck reaction. J. Am. Chem. Soc. 2005, 127, 3298-3299.

[107] Cassol, C. C.; Umpierre, A. P.; Ebeling, G.; Ferrera, B.; Chiaro, S. S. X.; Dupont, J., On the extraction of aromatic compounds from hydrocarbons by imidazolium ionic liquids. Int. J. Mol. Sci. 2007, 8, 593-605.

[108] Dupont, J.; Suarez, P. A. Z., Physico-chemical processes in imidazolium ionic liquids. Phys. Chem. Chem. Phys. 2006, 8, 2441-2452.

[109] Alias, A.; Hamzah, N.; Yarmo, M. A., Hydrogenolysis of Glycerol to Propanediols Over Nano-Ru/C Catalyst with Ionic Liquid Addition. Adv Mater Res-Switz 2011, 173, 49-54.

[110] Zakzeski, J.; Bruijnincx, P. C. A.; Jongerius, A. L.; Weckhuysen, B. M., The Catalytic Valorization of Lignin for the Production of Renewable Chemicals. Chem. Rev. 2010, 110, 3552-3599.

[111] Xiao, F.; Zhao, F.; Mei, D.; Mo, Z.; Zeng, B., Nonenzymatic glucose sensor based on ultrasonic-electrodeposition of bimetallic PtM (M=Ru, Pd and $\mathrm{Au})$ nanoparticles on carbon nanotubes-ionic liquid composite film. Biosens. Bioelectron. 2009, 24, 3481-3486.

[112] Xiao, F.; Zhao, F.; Zeng, J.; Zeng, B., Novel alcohol sensor based on PtRuNi ternary alloy nanoparticles-multi-walled carbon nanotube-ionic liquid composite coated electrode. Electrochem. Commun. 2009, 11, 1550-1553.

[113] Cadix, L.; Fuchs, C.; Rousseau, M.; Leduc, P.; Chaabouni, H.; Thuaire, A.; Brocard, M.; Valentian, A.; Farcy, A.; Bermond, C.; Sillon, N.; Ancey, P. Flechet, B., Integration and frequency dependent parametric modeling of through silicon via involved in high density 3D chip stacking. ECS Trans. 2010, 33, 1-21.

[114] Leduc, P., Enabling technologies for 3D chip stacking In VLSI Technology, Systems and Applications., IEEE: Hsinchu, Taiwan, 2008; pp 76-78.

[115] Leduc, P.; Assous, M.; Bouchu, D.; Roman, A.; Heitzmann, M.; Charlet, B.; Di Cioccio, L.; Zussy, M.; Mage, L.; Vandroux, L.; Deronzier, E.; Roule, A.; Haumesser, P.-H.; Sillon, N., The effect of process parameters on electrical properties of high density through-Si vias. Mater. Res. Soc. Symp. Proc 2009, 1112, No pp given, Paper \#: 1112-E03-03.

[116] Barriere, C.; Alcaraz, G.; Margeat, O.; Fau, P.; Quoirin, J. B.; Anceau, C.; Chaudret, B., Copper nanoparticles and organometallic chemical liquid deposition (OMCLD) for substrate metallization. J. Mat. Chem. 2008, 18, 3084-3086.

[117] Ham, Y.-H.; Kim, D.-P.; Baek, K.-H.; Park, K.-S.; Kim, M.; Kwon, K.-H.; Lee, K.; Doa, L.-M., Metal/Dielectric Liner Formation by a Simple Solution Process for through Silicon via Interconnection. Electrochem.Solid-State Lett. 2012, 15, H145-H147.

[118] Arquilliere, P.; Haumesser, P. H.; Santini, C. C., Copper nanoparticles generated in situ in imidazolium based ionic liquids. Microelectron. Eng. 2012 92, 149-151.

[119] Arquillière, P.; Helgadotir, I. S.; Haumesser, P. H.; Santini, C. C. Composition for the synthesis of bimetallic nanoparticles in an ionic liquid and associated method. French Patent Application FR1153743 2012.

[120] Haumesser, P.-H.; Basset, J.-M.; Campbell, P.; Deleonibus, S.; Gutel, T. Marchand, G.; Santini, C. Method for producing electrical interconnection made of carbon nanotubes. 2010-EP 53839 2010108957, 20100324., 2010.

[121] Deleonibus, S.; Basset, J.-M.; Campbell, P.; Gutel, T.; Haumesser, P.-H. Marchand, G.; Santini, C. Method for manufacturing a memory device with conductive nanoparticles. 2010- WO-157354 2234115, 20100323., 2010. 